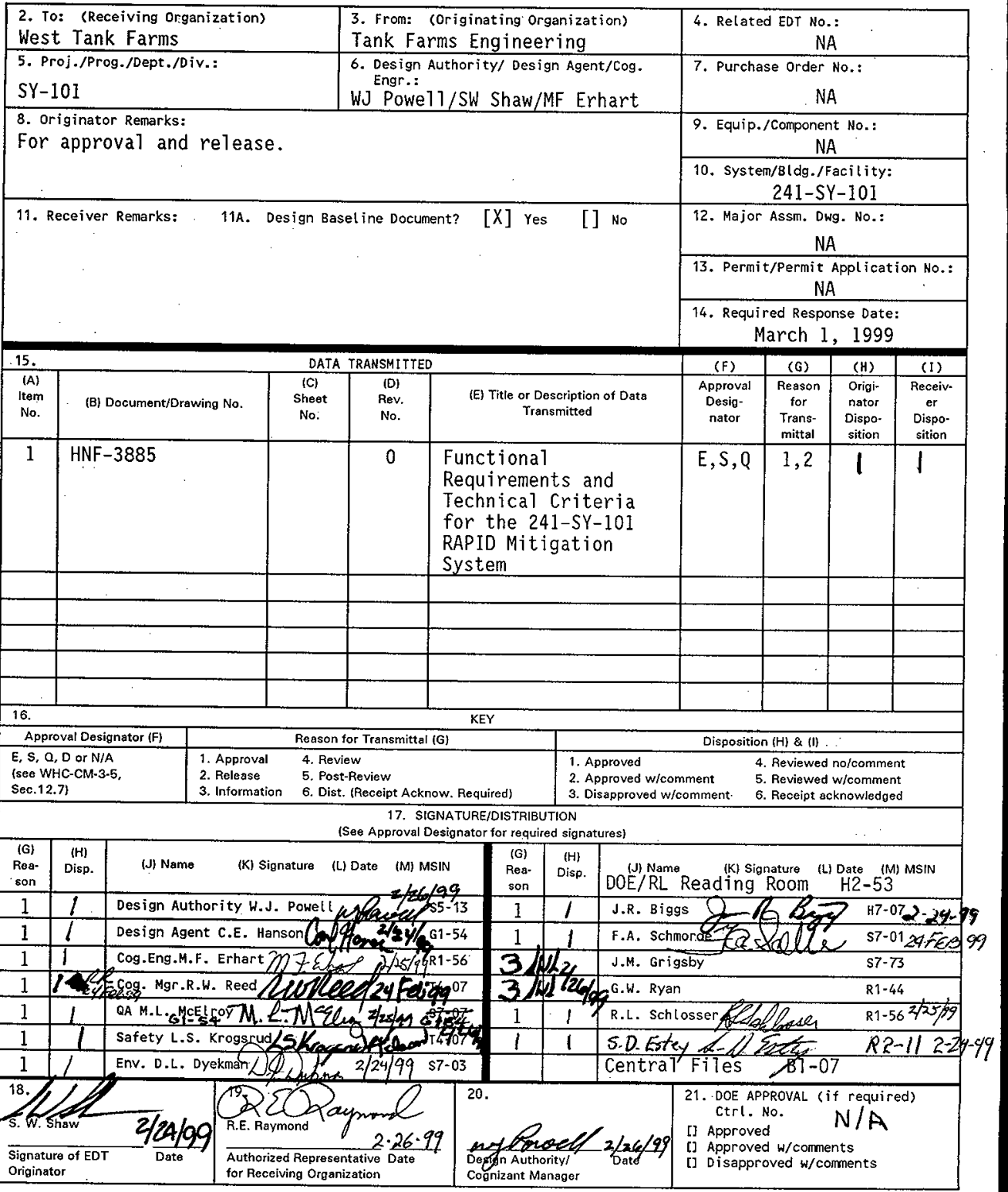




\title{
Functional Requirements and Technical Criteria for the 241-SY-101 RAPID Mitigation System
}

\author{
M. F. Erhart \\ Lockheed Martin Hanford Company \\ Richland, WA 99352 \\ U.S. Department of Energy Contract DE-AC06-96RL13200
EDT/ECN: $625911 \quad$ UC: 2070
Org Code: $747300 \quad$ Charge Code: 108968BA10
B\&R Code: EW3120074 Total Pages: 5961

$$
\text { KN }
$$

Key Words: SY-101, Mitigation, Transfer, overground, Pump, PPP, piping, pump pit, drop leg, New Generation Transfer Pump, NGTP, prefabricated pump pit

Abstract: This document provides functional, performance, and design criteria for the RAPID Mitigation system. In addition, critical interface, design assumptions, and analytical requixements are identified.

TRADEMARK DISCLAIMER. Reference herein to any specific commercial product, process, or service by trade name, trademark, manufacturer, or otherwise, does not necessarily constitute or imply its endorsement, recommendation, or favoring by the United States Government or any agency thereof or its contractors or subcontractors.

Printed in the United States of America. To obtain copies of this document, contact: Document Control Services, P.O. Box 950, Mailstop H6-08, Richland WA 99352, Phone (509) 372-2420; Fax (509) 376-4989.

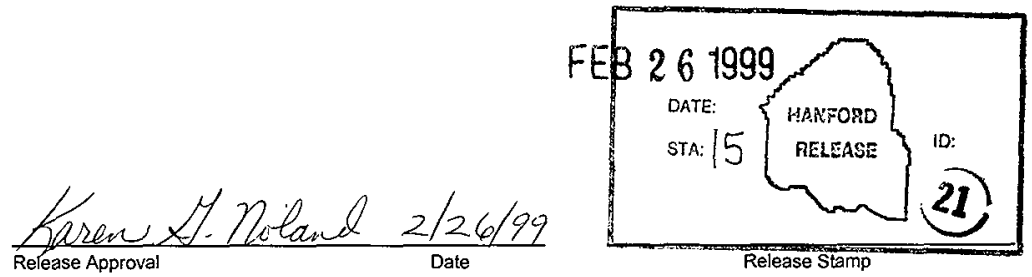




\title{
HNF-3885
}

Rev. 0

\section{FUNCTIONAL REQUIREMENTS AND TECHNICAL \\ CRITERIA FOR THE 241-SY-101 RAPID MITIGATION SYSTEM}

\author{
BY \\ Steven W. Shaw \\ Merrick \& Co. \\ February 24, 1999 \\ CONTACT \\ M. F. Erhart \\ Lockheed Martin Hanford Company
}




\section{HNF-3885}

Rev. 0

Feb. 24, 1999

\section{Table of Contents}

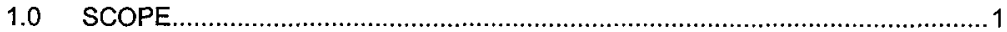

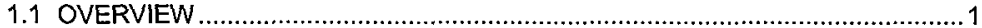

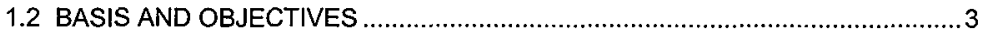

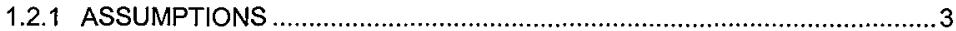

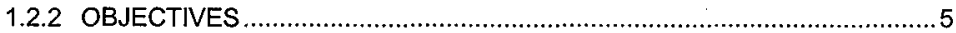

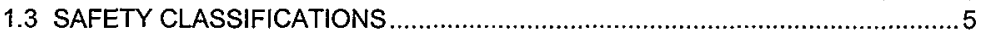

2.0 TERMS, DEFINITIONS, AND SYMBOLS ............................................... 8

3.0 APPLICABLE DOCUMENTS AND INFORMATION .................................... 9

3.1 APPLICABLE HANFORD STANDARD DESIGN CRITERIA AND PRACTICES ... 9

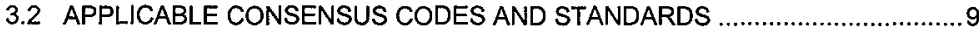

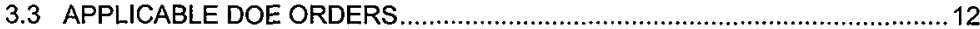

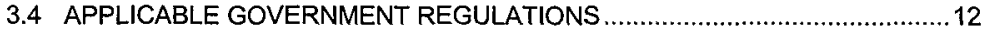

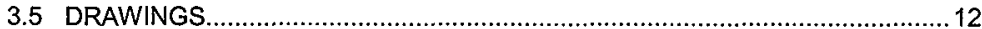

3.6 REFERENCES, OTHER DOCUMENTS AND INFORMATION $\ldots \ldots \ldots \ldots \ldots \ldots \ldots . . \ldots \ldots$

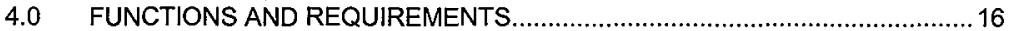

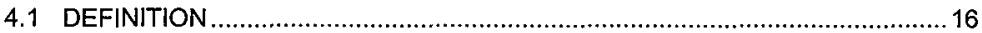

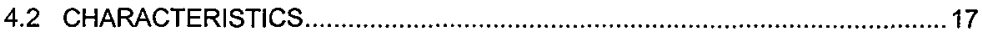

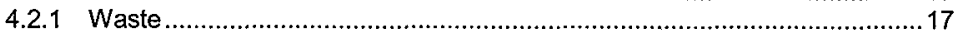

4.2.2 New Generation Transfer Pump ....................................................... 17

4.2.3 Prefabricated Pump Pit...................................................................... 17

4.2.4 Transfer Line and Drop Leg ............................................................... 17

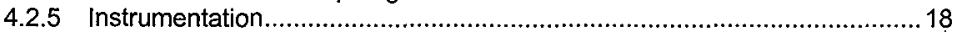

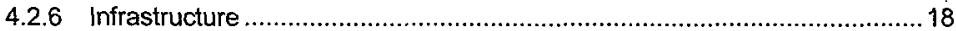

4.3 TECHNICAL DESIGN REQUIREMENTS, CONSTRAINTS, AND CRITERIA .... 19

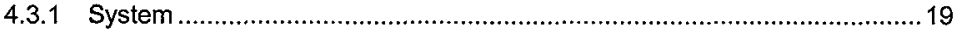

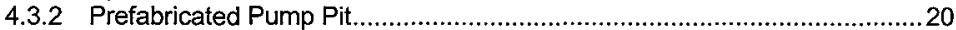

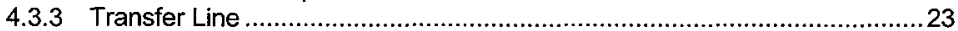

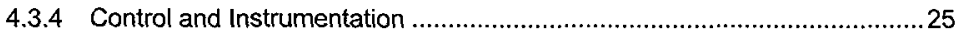

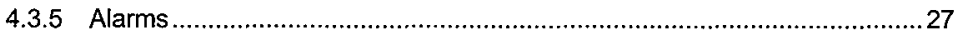

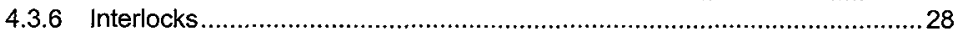

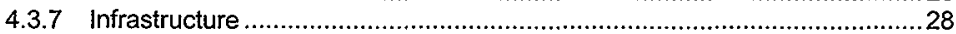

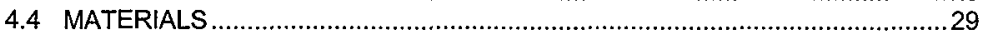

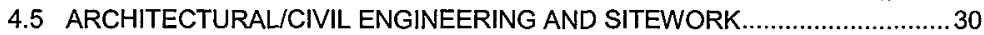

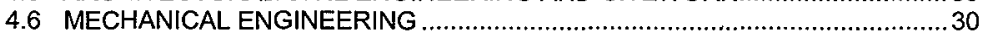

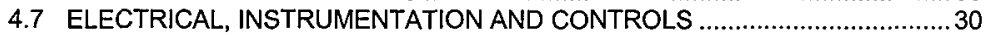

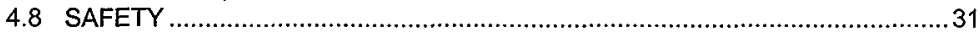

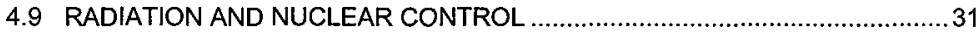

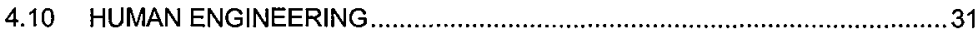

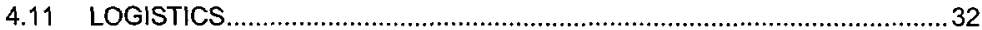

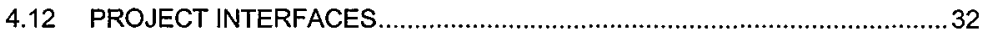

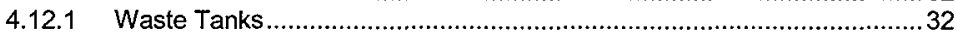

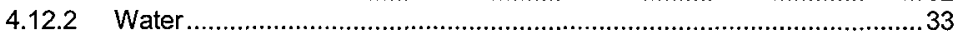

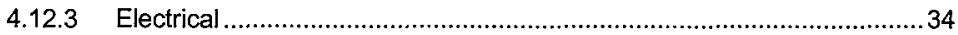

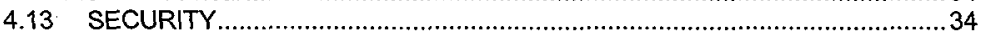

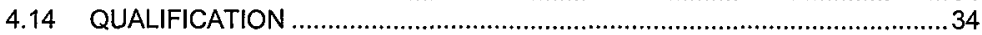

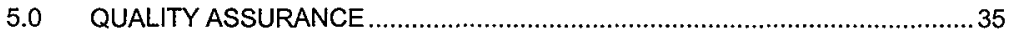

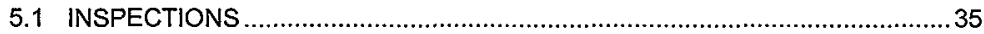


HNF-3885

Rev. 0

Feb. 24, 1999

5.2 TEST AND EXAMINATIONS 35

6.0 TURNOVER

\section{APPENDICIES}

Appendix A Internal Memo

Appendix B FGEAB Meeting Minutes

Appendix $C$ Process Flow Diagram

Appendix D NGTP Flange Interface Drawings

Appendix E Internal Memo (Draft)

\section{TABLES}

1-1 New Generation Transfer Pump Design Data

4-1 Instrumentation/Alarm Indication Location

4-2 RAPID System Interface Table 
HNF-3885

Rev. 0

Feb. 24, 1999

\section{FUNCTIONAL REQUIREMENTS AND TECHNICAL CRITERIA FOR THE 241-SY-101 RAPID MITIGATION SYSTEM}

1.0

\section{SCOPE}

\section{OVERVIEW}

Tank 241-SY-101 (SY-101) has recently exhibited a steady waste surface level growth. A path forward to mitigate the SY-101 surface level growth issue has been developed (Reference A). The project has been directed to install the necessary equipment to transfer $380-570 \mathrm{~m}^{3}(100,000$ 150,000 gallons) of waste from SY-101 to SY-102 before the waste elevation reaches the region of the tank where the transition from a double to a single shell tank occurs. It is assumed that the SY-101 waste is compatible with that in SY-102.

To accomplish this primary objective will require that the system design, fabrication, equipment installation, and the first waste transfer be completed prior to September 24, 1999. Further transfers may be required over the next five years.

The Respond and Pump in Days (RAPID) Mitigation System is comprised of a number of components and sub-assemblies. Major

components/assemblies/upgrades associated with the system include:

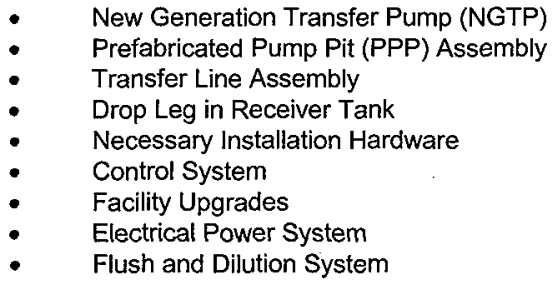

The transfer pump is the general service component around which the remaining equipment comprising the RAPID Mitigation System is arranged. The New Generation Transfer Pump's nominal design values are identified in Table 1-1.

The PPP provides the interface between a number of the key components and subsystems contained within the SY-101 RAPID Mitigation System. The design of the PPP assembly includes piping and control valves necessary to allow flushing of the transfer line, pump bearings, and pump internals. The PPP assembly is the "adapter" that 
HNF-3885

Rev. 0

Feb. 24, 1999

provides for connection at the encased transfer line and the transfer pump/pipeline flush connections.

The RAPID system design includes a dedicated transfer line (not physically connected to other active or inactive waste transfer lines) from the PPP installation to SY-102. Transfer system leak detectors are installed at all low points. The number of low points shall be minimized to the extent practicable.

A drop leg is required for installation into the receiver tank. The drop leg will discharge waste being transferred from SY-101 below the waste surface of SY-102. The design of the drop leg shall be configured to maximize the horizontal discharge velocity into the tank without significantly increasing the potential for plugging in the leg or nozzle that would preclude further transfers from SY-101.

\section{TABLE 1-1}

NEW GENERATION TRANSFER PUMP DESIGN DATA

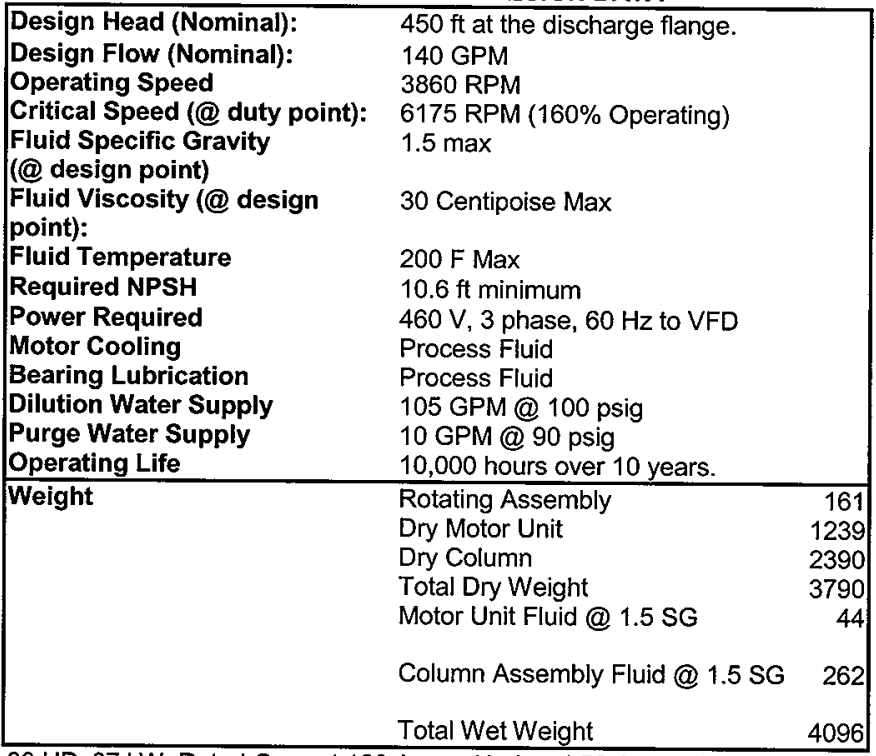

$60 \mathrm{HP}, 67 \mathrm{~kW}$, Rated Current 120 Amps, No-Load 50 Amps, Locked Rotor Current 255 Amps.

Screen Slze:

0.25 in diameter 


$$
\text { HNF-3885 }
$$

Rev. 0

Feb. 24, 1999

The RAPID Mitigation System's control system is comprised of all instrumentation and control functions necessary to accomplish waste transfers between SY-101 and SY-102. Control functions include system configuration of waste, service water, dilution water, and flush water line routing. Instrumentation provides feedback to operations with respect to operating parameters and system status. The control system shall provide the minimum amount of remote/automatic control possible, relying instead upon operator inputs and procedural and/or other administrative controls to ensure proper system operating configuration and control.

Infrastructure upgrades are required to support the deployment and operation of the RAPID Mitigation System. Facility upgrades include the supply of electrical power to the transfer pump's Variable Frequency Drive (VFD), providing heated raw water to meet transfer system requirements for dilution during waste transfer, the provision of instrument and service air supplies for instrumentation and process requirements as required. All efforts will be made to minimize the number of field modifications required by the design.

\section{ASSUMPTIONS}

It is necessary to make a number of assumptions to facilitate a schedule that requires the system design, fabrication, equipment installation, and the first waste transfer be completed prior to September 24, 1999. Further transfers may be required over the next five years. To meet this schedule requirement, the following assumptions have been made:

1.2.1.1 The waste transferred from SY-101 will be compatible with the waste in SY-102.

1.2.1.2 Transfers will be made as necessary to/from $S Y-102$ to ensure sufficient room is available for transfers from SY-101, and contains sufficient waste to keep the discharge nozzles of the drop leg installed in 102 submersed.

1.2.1.3 PE Stamping of design media shall not be required as per the Chief Engineer, Lockheed Martin Hanford Company.

1.2.1.4 Radiation fields during waste transfers may be in excess of those normally observed in the Tank Farms. Due to dome load constraints, time and distance may be the primary method of maintaining radiation exposure ALARA.

1.2.1.5 The New Generation Transfer Pump and VFD will be utilized and are suitable for this application. 
HNF-3885

Rev. 0

Feb. 24, 1999

1.2.1.6 It is more cost effective, and best meets mission requirements, to replace the transfer pump if it is damaged beyond serviceability by seismic event rather than modify the pump to withstand seismic loads for which it was not designed.

1.2.1.7 The primary transfer line is classified as a general service component.

1.2.1.8 Heat trace is only required on new transfer line piping outside the PPP.

1.2.1.9 It will not be required that the transfer line encasement comply with the requirements of Section III of the ASME Boiler and Pressure Vessel code. The ASME B31.3 Process Piping code with additional inspection requirements will be used to ensure that the encasement integrity is suitable for its safety class function.

1.2.1.10 Existing spare conduits between the vicinity of DACS trailer and tank 101SY are available and sufficient.

1.2.1.11 Adequate power is available at substation 242-S and MCC SY272-EDSMCC-003.

1.2.1.12 Leak detection shall not be connected into any site wide alarm system (i.e. CASS, TMACS) but only locally alarm and send a single alarm to the DACS trailer. It is assumed that Operations will respond to any leak detector alarm in 30 minutes or less.

1.2.1.13 Power $(120 \mathrm{~V})$ is readily available in the farm for I \& C.

1.2.1.14 Pressure readouts are local to their assumed sensing locations at the transfer pump and dilution water supply, with no readouts in the DACS trailer.

1.2.1.15 $\quad 1 \& \mathrm{C}$ remains simple and non-interlocking to the transfer pump with the exception of the following:

- An interlock provided from the raw water supply to the transfer pump shutdown circuit (i.e. VFD input). Upon loss of or lessening Water pressure/flow-rate a shutdown signal will be sent to the VFD.

- A feature to prevent inadvertent water addition to the waste tanks will be designed.

1.2.1.16 A water pump skid is required, portable, and powered from an available welding outlet.

1.2.1.17 If supplemental water heat is required, diesel generators will be obtained to power the heating units. 


\section{HNF-3885}

Rev. 0

Feb. 24, 1999

1.2.1.18 Water booster pump is portable and powered from existing MCC building welding outlet if needed.

1.2.1.19 In the service water pit, indication of total raw water flow (totalizer readout) will only be local, and not available in the DACS trailer.

1.2.1.20 The magnetic flow meters for the raw water (dilution) supply system will be safety significant components.

1.2.1.21 Installation of a mass-flow meter in any of the transfer lines will not be required.

1.2.1.22 Seal Loop water level will be detected by a reverse acting leak detection sensor/circuit that will alarm at the PPP and also in the DACS trailer.

1.2.1.23 No Safety Class or Safety Significant power is required.

1.2.1.24 NFPA 497A Hazardous Classification will be designed to be nonclassified for the pump pit and surrounding areas.

The near term desired end state of the waste transfer is to regain sufficient reserve operational head space within SY-101 to allow routine operations to occur without the concern of waste impacting the operation of equipment or reaching unacceptable levels within the tank.

The long term desired end state is to have sufficient amounts of the tank material either treated or removed so continued operation of the SY-101 Mixer pump is no longer required. The safety issue will be closed and there will be no open Unreviewed Safety Questions (USQs) against tank SY-101.

The Safety Related Components that have been established for waste transfer-related accidents in the BIO will also apply to this proposed activity as appropriate to remain consistent with the TWRS BIO:

\section{Safety Class SSCs}

Transfer System Covers. The safety function of the transfer system covers is (1) to provide a physical barrier to knock down spray and limit release of aerosols to the atmosphere in case of a release during a transfer and (2) to limit release of aerosols generated by splatter inside the pit and limit shine and skyshine dose to the onsite receptor. [The second safety function is safety significant.] 


$$
\text { HNF-3885 }
$$

Rev. 0

Feb. 24, 1999

Pressure Switch Interlock(s) or Alarm to Waste Transfer Pumps (Raw Water and Other Water Service Supply Lines). The safety function of the pressure switch interlocks to waste transfer pumps is to prevent backflow of waste into interconnecting systems.

Transfer Leak Detection System. The safety function of the transfer leak detection system is to detect waste accumulation in the pits and the transfer pump auto stop or alarm function.

Primary Tank Leak Detection For Double-Shell Tanks. The safety function of the annulus leak detector in a DST is to detect waste accumulation in the DST annulus.

Waste Transfer Pipe Encasements. The safety function of waste transfer pipe encasements is to ensure that a leak in the primary waste transfer system piping is directed to a waste transfer-associated structure.

\section{Stack Continuous Air Monitor and Interlock to Exhaust Fan on All Actively Ventilated Tanks. The safety function of the stack continuous air monitor and interlock to exhaust fan is to detect radioactivity caused by failure of a high-efficiency particulate air (HEPA) filter and the shut-off of the exhaust fan for all actively ventilated tanks.}

\section{Safety Significant SSCs}

Raw Water or Service Water System Backflow Preventers. The safety function of backflow preventers is to prevent the backflow of waste into raw water or service water systems.

Tank Level Monitors. The safety function of level monitors is to indicate the waste level in the tank to support material balance calculations during waste transfers.

Service Water Flow Totalizers. The safety function of the service water flow totalizers is to monitor flow of service water.

The transfer-related TSRs listed in HNF-SD-WM-TSR-006 are applicable to this Proposed Activity. These include:

LCO 3.1.1, Transfer System Covers

LCO 3.1.2, Service Water Pressure Detection Systems

LCO 3.1.3, Transfer Leak Detection Systems

LCO 3.1.4, Ventilation Stack CAM Interlock Systems

LCO 3.2.6, Primary Tank Leak Detection Systems

AC 5.12, Transfer Controls

AC 5.13, Encasement Seal Loop Controls

AC 5.14, Emergency Preparedness

AC 5.17, Excavation Controls 
HNF-3885

Rev. 0

Feb. 24, 1999

AC 5.19, Process instrumentation and Measuring and Test Equipment AC 5.20, Transfer Pump Administrative Lock Controls

AC 5.21, Tank Service Water Intrusion Monitoring Program

AC 5.22,. Transfer System Cover Removal Controls 
HNF-3885

Rev. 0

Feb. 24, 1999

$\begin{array}{ll}\text { ABU } & \text { Acceptance for Beneficial Use } \\ \text { ACI } & \text { American Concrete Institute } \\ \text { AISC } & \text { American Institute of Steel Construction } \\ \text { ALARA } & \text { As-Low-As-Reasonably-Achievable } \\ \text { ANSI } & \text { American National Standard Institute } \\ \text { BIO } & \text { Basis for Interim Operation } \\ \text { BPA } & \text { Bonneville Power Administration } \\ \text { CAM } & \text { Continuous Air Monitor } \\ \text { cC } & \text { cubic centimeter } \\ \text { CFR } & \text { Code of Federal Regulations } \\ \text { cP } & \text { Centipoise } \\ \text { DACS } & \text { Data Acquisition and Control System } \\ \text { DST } & \text { Double Shell Tank } \\ \text { ECN } & \text { Engineering Change Notice } \\ \text { g } & \text { gram } \\ \text { GPM } & \text { Gallons Per Minute } \\ \text { HEPA } & \text { High Efficiency Particulate Air-filter } \\ \text { HMS } & \text { Hanford Meteorological Service } \\ \text { HVAC } & \text { Heating, Ventilating and Air Conditioning } \\ \text { LANL } & \text { Los Alamos National Laboratory } \\ \text { lbf } & \text { pounds force } \\ \text { NFPA } & \text { National Fire Protection Association } \\ \text { NGTP } & \text { New Generation Transfer Pump } \\ \text { PPP } & \text { Prefabricated Pump Pit } \\ \text { QAPP } & \text { Quality Assurance Program Plan } \\ \text { RAPID } & \text { Respond and Pump in Days } \\ \text { SA } & \text { Safety Assessment } \\ \text { SG } & \text { Specific Gravity } \\ \text { SSC } & \text { Systems, Structures, and Components } \\ \text { TBD } & \text { To Be Determined } \\ \text { TWRS } & \text { Tank Waste Remediation System } \\ \text { USQ } & \text { Unreviewed Safety Question } \\ \text { VFD } & \text { Variable Frequency Drive } \\ & \end{array}$


HNF-3885

Rev. 0

Feb. 24, 1999

The following documents form a part of these requirements to the extent specified herein. PRACTICES

HNF-PRO-097 Engineering Design and Evaluation

HNF-PRO-704 Hazard and Accident Analysis Process

HNF-PRO-1621 ALARA Decision Making Methods

HNF-PRO-1622 Radiological Design Review Process

HNF-PRO-1819 PHMC Engineering Requirements

HNF-IP-0842 TWRS Administration Manual, Volume IV, "Engineering"

These are the Codes and Standards identified at this time. Others may be identified as the design progresses. The latest issue of codes and standards shall be used.

$\mathrm{ACl}$

\section{American Concrete Institute}

\section{P.O. Box 19150}

Detroit, MI 48219

$\mathrm{ACl}-301$

$\mathrm{ACl}-318$

$\mathrm{ACl}-349$

AISC

AISC

ANS
Specification for Structural Concrete for Buildings Building Code Requirements for Reinforced Concrete Code Requirements for Nuclear Safety Related Concrete Structures

American Institute of Steel Construction 400 North Michigan Avenue Chicago, IL 60611

Manual of Steel Construction

American Nuclear Society 555 North Kensington Avenue LaGrange Park, IL 60525 
HNF-3885

Rev. 0

Feb. 24, 1999

ANS 6.4

Guidelines on the Nuclear Analysis and Design of Concrete Radiation Shielding for Nuclear Power Plants

ANSI

American National Standards Institute 1430 Broadway

New York, NY 10018

ANSI B30

Hoisting and Rigging Standards

ANSI N512

Protective Coatings (Paint) for the Nuclear Industry

ASME

American Society of Mechanical Engineers

22 Law Drive

Box 2300

Fairfield, NJ 07007

ASME

ASME B31.1

Boiler and Pressure Vessel Code

ASME B31.3

Power Piping

ASME N509

Process Piping

ASME N510

Nuclear Power Plant Air Cleaning Units and Components

ASME NQA-1 Testing of Nuclear Air Cleaning System

Quality Assurance Program Requirements for Nuclear

Facilities

ASTM

ASTM

1916 Race Street

Philadelphia, PA 19103

ASTM A312 Specification for Seamless and Austenitic Stainless Steel Pipe

AWS
American Welding Society
550 NW LeJeune Road
P.O. Box 351040
Miami, FL 33135

AWS D1.1

Structural Welding Code - Steel

AWS D5.2

Standard for Welded Steel, Elevated Tanks, Standpipes, and Reservoirs for Water Storage

BOCA

Building Officials and Code Administrators

International, Inc.

4051 West Flossmoor Road

Country Club Hills, IL 60477

BOCA Basic/National Mechanical Code 
HNF-3885

Rev. 0

Feb. 24, 1999

DOD

U. S. Department of Defense

Attention: NPFC Code 1052

Naval Publications and Forms Center

5801 Tabor Avenue

Philadelphia, PA 19120-5099

DOD

MIL-STD-1472C, Human Engineering Design Criteria for Military Systems, Equipment, and Facilities

EPRI

Electric Power Research Institute

P.O. Box 10412

Palo Alto, CA 94303

EPRI NP-3659 Human Factors Guide for Nuclear Power Plant Control Room

IAPMO

International Association of Plumbing and Mechanical Officers 5032 Alhambra Avenue Los Angeles, CA 90032-3490

IAPMO

UPC, Uniform Plumbing Code

ICBO

International Conference of Building Officials 5360 South Workman Road Mill Road Whittier, CA 90601

ICBO

UBC (Uniform Building Code)

LLNL / UCRL

Lawrence Livermore National Laboratory

Livermore, CA 94550

UCRL 15673 Human Factors Design Guidelines for Maintainability of DOE Nuclear Facilities

NFPA

National Fire Protection Association

Batterymarch, Park

Quincy, MA 02269

NFPA 70

National Electrical Code (NEC)

NFPA 497A Classification of Class 1 Hazardous (Classified) Locations for Electrical Installations in Chemical Process Areas 
HNF-3885

Rev. 0

Feb. 24, 1999

APPLICABLE DOE ORDERS

\section{U.S. Department of Energy 1000 Independence Ave, SW Washington, DC 20585}

DOE 5480.11

DOE 5480.21

DOE 5480.4

DOE $6430.1 \mathrm{~A}$

DOE-RL-92-39
Radiation Protection for Occupational Workers Unreviewed Safety Questions

Environmental Protection, Safety, and Health Protection Standards

General Design Criteria

Hanford Site Hoisting and Rigging Manual

APPLICABLE GOVERNMENT REGULATIONS

Code of Federal Regulations

Superintendent of Documents

Government Printing Office

Washington, DC 20402

10 CFR 830

10 CFR 835

29 CFR 1910

29 CFR 1926

WAC 173-303

WAC 296-46
Quality Assurance

Occupational Radiation Protection

Occupational Health and Safety Standards

Safety and Health Regulations for Construction

Washington Administrative Code

State of Washington

Olympia, WA

Dangerous Waste Regulations

Installing Electric Wires and Equipment

DRAWINGS

$\begin{array}{lcccl}\begin{array}{l}\text { Drawing } \\ \text { Number }\end{array} & \text { Sheet Rev. } & \text { Date } & \text { Title } \\ \text { H } 140100573 & 1 & 0 & 10 / 2 / 96 & \text { DRAWING LIST \& AREA MAP } \\ \text { H } 140100586 & 1 & 0 & 3 / 31 / 97 & \text { DRAWING LIST \& AREA MAP } \\ \text { H } 140100586 & 2 & 0 & 3 / 31 / 97 & \text { DRAWING LIST \& AREA MAP } \\ \text { H } 140100586 & 1 & 0 & 3 / 31 / 97 & \text { DRAWING LIST \& AREA MAP } \\ \text { H } 140100586 & 2 & 0 & 3 / 31 / 97 & \text { DRAWING LIST \& AREA MAP }\end{array}$


HNF-3885

Rev. 0

Feb. 24, 1999

\begin{tabular}{|c|c|c|c|c|}
\hline $\begin{array}{l}\text { Drawing } \\
\text { Number }\end{array}$ & & Rev. & Date & Title \\
\hline H 140100573 & 1 & 0 & 10/2/96 & DRAWING LIST \& AREA MAP \\
\hline H 140100587 & 1 & 0 & $3 / 31 / 97$ & CIVIL SITE PLAN 241-SY TANK FARM \\
\hline H 020037778 & 1 & 6 & $12 / 16 / 92$ & PIPING PLAN TANKS $101102: \& 103$ \\
\hline H 020037778 & 2 & 5 & $12 / 16 / 95$ & PIPING PLAN TANKS $101102 \& 103$ \\
\hline 0037778 & 3 & 1 & $1 / 7 / 93$ & PIPING PLAN 241-SY TANK FARM \\
\hline H 020037780 & 1 & 7 & $5 / 20 / 97$ & PIPING PLAN VALVE PITS 241-SY-A \& B \\
\hline H 020037781 & 1 & 3 & $2 / 19 / 93$ & $\begin{array}{l}\text { PIPING SECTS \& DETAILS VALVE PITS } \\
241-S Y-A \text { \& B }\end{array}$ \\
\hline H 020037783 & 1 & 5 & 2/13/96 & $\begin{array}{l}\text { PIPNG PLAN \& DETS PUMP PIT } \\
241 S Y-01 A, 02 A, 03 A\end{array}$ \\
\hline H 020037785 & 1 & 3 & $3 / 19 / 93$ & $\begin{array}{l}\text { PIPING PLAN \& DETAILS ANNULUS } \\
\text { PUMP PIT } 241-S Y-01 B, 03 B\end{array}$ \\
\hline H 140010531 & 1 & 0 & $4 / 23 / 98$ & $\begin{array}{l}\text { DOME PENETRATION SCHEDULES } \\
\text { (WST } M \text { WSTA) TANK } 241-S Y-101\end{array}$ \\
\hline H 140010531 & 2 & 0 & $4 / 23 / 98$ & $\begin{array}{l}\text { DOME PENETRATION SCHEDULES } \\
\text { (WSTMSTA) TANK } 241-S Y-102\end{array}$ \\
\hline H 140010531 & 3 & 0 & $4 / 23 / 98$ & $\begin{array}{l}\text { DOME PENETRATION SCHEDULES } \\
\text { (WSTMSTA) TANK } 241-S Y-103\end{array}$ \\
\hline 140100598 & 1 & 0 & $3 / 31 / 97$ & PLAN TANK 241-SY-102 \\
\hline H 140100599 & 1 & 0 & $3 / 31 / 97$ & $\begin{array}{l}\text { YY-102 PLAN, } \\
\text { ILS }\end{array}$ \\
\hline H 140100599 & 2 & 0 & $3 / 31 / 97$ & $\begin{array}{l}\text { PIPING TANK } 241-S Y-102 \text { SECTION \& } \\
\text { DETAILS }\end{array}$ \\
\hline H 140100599 & 3 & 0 & $3 / 31 / 97$ & $\begin{array}{l}\text { PIPING TANK 241-SY-102 PLAN, } \\
\text { SECTIONS \& DETAILS }\end{array}$ \\
\hline H 140100599 & 4 & 0 & $3 / 31 / 97$ & $\begin{array}{l}\text { PIPING TANK 241-SY-102 PLAN \& } \\
\text { SECTIONS }\end{array}$ \\
\hline H 140100599 & 5 & 0 & $3 / 31 / 97$ & $\begin{array}{l}\text { PIPING TANK 241-SY-102 PLAN \& } \\
\text { SECTIONS }\end{array}$ \\
\hline H 020037770 & 1 & 9 & $4 / 7 / 98$ & $\begin{array}{l}\text { ENGINEERING FLOW DIAGRAM } \\
\text { MISCELLANEOUS }\end{array}$ \\
\hline H 020037770 & 2 & 4 & $5 / 21 / 98$ & $\begin{array}{l}\text { ENGINEERING FLOW DIAGRAM } \\
\text { MISCELLANEOUS }\end{array}$ \\
\hline 037771 & 1 & 2 & $1 / 1 / 77$ & IC DIAGRAM TK-101,102+103 \\
\hline H 140100701 & 1 & 0 & $3 / 31 / 97$ & $\begin{array}{l}\text { ELECTRICAL TANK 241-SY-102 ONE } \\
\text { LINE DIAGRAM }\end{array}$ \\
\hline 037732 & 1 & 9 & $4 / 14$ & ELECTRICAL SITE PLAN \\
\hline 037732 & 2 & 1 & $12 / 1$ & ELEC \\
\hline H 020037732 & 3 & 0 & $7 / 8 / 93$ & ELECTRICAL SITE PLAN \\
\hline H 020037734 & 1 & 16 & $7 / 16 / 98$ & ELECTRICAL INSTM HOUSE PLANS \\
\hline 037736 & 1 & 7 & 4/7/97 & ELECTRICAL DETAILS \\
\hline H 020037736 & 2 & 1 & $2 / 2 / 96$ & ELECTRICAL DETAILS \\
\hline H 020038373 & 1 & 1 & $2 / 1 / 76$ & $\begin{array}{l}\text { ELECT LEAK DETECTION ALARM } \\
S, S X, S Y+U \text { TK FARMS }\end{array}$ \\
\hline H 020046789 & 1 & 7 & $6 / 11 / 97$ & $\begin{array}{l}\text { ELEC/INSTR PLANS EL DET \& ELEM } \\
\text { DIAGS }\end{array}$ \\
\hline
\end{tabular}


HNF-3885

Rev. 0

Feb. 24, 1999

\begin{tabular}{|c|c|c|c|c|}
\hline Drawing & Shee & Rev. & Date & Title \\
\hline H 020046789 & 2 & 1 & $9 / 30 / 92$ & $\begin{array}{l}\text { ELEC/INSTR PLANS EL DET \& ELEM } \\
\text { DIAGRAMS }\end{array}$ \\
\hline H 140100572 & 1 & 0 & $3 / 8 / 96$ & $\begin{array}{l}\text { ELECTRICAL CATHODIC } \\
\text { PROTECTION PLAN (EN) }\end{array}$ \\
\hline H 140100720 & 1 & 0 & $3 / 31 / 97$ & $\begin{array}{l}\text { ELECTRICAL TANK 241-SY-102 } \\
\text { CATHODIC PROTECTION PLAN }\end{array}$ \\
\hline H 140100721 & 1 & 0 & $3 / 31 / 97$ & $\begin{array}{l}\text { ELECTRICAL TANK } 241 \text {-SY-102 } \\
\text { CATHODIC PROTECTION DETAILS }\end{array}$ \\
\hline H 140100571 & 1 & 0 & $3 / 8 / 96$ & $\begin{array}{l}\text { ELECTRICAL CATHODIC } \\
\text { PROTECTION SCHEMATIC (EN) }\end{array}$ \\
\hline H 140100500 & 1 & 0 & $3 / 26 / 96$ & $\begin{array}{l}\text { SY TANK FARM UNDERGROUND } \\
\text { CONDUIT LAYOUT AND DETAILS }\end{array}$ \\
\hline H 140100500 & 2 & 0 & $3 / 26 / 96$ & $\begin{array}{l}\text { SY TANK FARM UNDERGROUND } \\
\text { CONDUIT LAYOUT AND DETAILS }\end{array}$ \\
\hline H 140100501 & 1 & 0 & $3 / 26 / 96$ & $\begin{array}{l}\text { TANK SY-101 UNDERGROUND } \\
\text { CONDUIT LAYOUT AND DETAILS }\end{array}$ \\
\hline H 140100501 & 2 & 0 & $3 / 26 / 96$ & $\begin{array}{l}\text { TANK SY-101 UNDERGROUND } \\
\text { CONDUIT LAYOUT AND DETAILS }\end{array}$ \\
\hline H 140100502 & 1 & 0 & $3 / 26 / 96$ & $\begin{array}{l}\text { TANK SY-102 UNDERGROUND } \\
\text { CONDUIT LAYOUT AND DETAILS }\end{array}$ \\
\hline H 140100602 & 1 & 0 & $3 / 31 / 97$ & $\begin{array}{l}\text { JUMPER ARRANGEMENT PUMP PIT } \\
241-S Y-02 A\end{array}$ \\
\hline H 140100602 & 2 & 0 & $3 / 31 / 97$ & $\begin{array}{l}\text { JUMPER ARRANGEMENT PUMP PIT } \\
241-S Y-02 A \text { NOZ LOCATIONS }\end{array}$ \\
\hline H 140100603 & 1 & 0 & $3 / 31 / 97$ & $\begin{array}{l}\text { JUMPER ARRANGEMENT VALVE PIT } \\
241-\text { SY-A }\end{array}$ \\
\hline H 140100604 & 1 & 0 & $3 / 31 / 97$ & $\begin{array}{l}\text { JUMPER ARRANGEMENT VALVE PIT. } \\
241-S Y-B\end{array}$ \\
\hline H 140100606 & 1 & 0 & $3 / 31 / 97$ & $\begin{array}{l}\text { PIPING VALVE PIT 241-SY-A } \\
\text { MODIFICATIONS }\end{array}$ \\
\hline H 140100607 & 1 & 0 & $3 / 31 / 97$ & $\begin{array}{l}\text { PIPING VALVE PIT 241-SY-B } \\
\text { MODIFICATIONS }\end{array}$ \\
\hline
\end{tabular}

A. Raymond, R. E., 1999, "Tank 241-SY-101 Surface Level Rise Remediation Project," HNF-3824, Rev. 0, Lockheed Martin Hanford Company, Richland, WA Feb.

B. Estey, S. D., 1999, "Anticipated Dynamic Viscosity and Solids Concentration of Slurries Produced During the Dilution and Transfer of Tank 241-SY-101 Wastes to Tank 241-SY-102," (Internal Memo number 74B50-99-017, to W. J. Powell, Feb. 11), Lockheed Martin Hanford Company, Richland, WA (See Appendix A). 
HNF-3885

Rev. 0

Feb. 24, 1999

C. Lindner, Toghiani and Barfied, 1998, "Thermodynamic Simulation of Hanford Tank 241-SY-101 Dissolution - Part 2: Supernate Transfer Followed by In-Tank Dillution.", Mississippi State University, Mississippi

D. Herting, D.L., et al, 1995, "Tank Characterization Report for Double-Shell Tank 241-SY-101," WHC-SD-WM-ER-409, Rev. 0, Westinghouse Hanford Company, Richland, WA, July

E. LMHC, 1999, "Tank Waste Remediation System Basis for Interim Operation, (BIO)", HNF-SD-WM-BIO-001, Revision 1-A, Lockheed Martin Hanford Company, Richland, Washington

F. Sullivan, L. Harold, 1996, WHC-SD-WM-SAD-033, Rev 2, "A Safety Assessment for Proposed Pump Mixing Operations to Mitigate Episodic Gas Releases in Tank 241-SY-101: Hanford Site, Richland, WA." Westinghouse Hanford Company, Richland, WA July.

G. Flammable Gas Equipment Advisory Board Meeting Minutes, January 19, 1999. (See Appendix B).

H. Hauck, F. M, 1994, WHC-S-0238, "Specification For Prototype Tank Farm Transfer Pumps with Submersible Motor," Westinghouse Hanford Company, Richland, WA August

I. Westinghouse, 1997, S.O. V001, "Model 2A-513-A1 Lead Unit Final Design Report Addendum," Westinghouse Electric Corporation, Electro-Mechanical Division, Cheswick, PA April

J. Carter, S. B., 1988, SD-RE-DGS-002, Rev. 3, "Jumper Design Standard," Westinghouse Hanford Company, Richland, WA Oct.

K. Conner, J. M., 1999, "Estimated Properties of Tank 241-SY-101 Waste Affecting Dilution and Transfer," (Internal Memo, DRAFT, to W. J. Powell, Feb. 26), Lockheed Martin Hanford Company, Richland, WA. (See Appendix E). 
HNF-3885

Rev. 0

Feb. 24, 1999

\section{DEFINITION}

The RAPID system is envisioned as a simple, dedicated transfer system that is used to transfer waste from SY-101 to SY-102. The system design will use an existing, available 42-inch riser for installation of the NGTP. This will be accomplished via the installation of a prefabricated pump pit around the riser that will provide the typical shielding, confinement, and drain functions provided by existing cast in place concrete pits.

To perform the waste transfer the waste is to be diluted at a nominal ratio of $1: 1$ with warm raw water injected at the NGTP suction. Similarly, post transfer flushing of the NGTP and the transfer line is accomplished using warm water. To ensure an adequate supply of water at the required flow rates and pressures (see Process Flow Diagram, Appendix C), the RAPID system design requires a water skid. Water is supplied from the tank farm water system to the water skid. The skid contains a number of pumps, and a water holding tank that ensures an adequate supply of transfer line flush water is available to flush the pump and transfer lines in the event of a disruption of the tank farm water supply.

Control of the RAPID system is to be accomplished without the use of remote/automatically operated equipment to the maximum extent practicable. This operational philosophy will enhance system reliability by reducing the number of components that could fail and require cessation of a transfer. Similarly, operator-training requirements are minimized.

The design for the RAPID system must provide for the repair or replacement of assemblies or components that have failed either during, or between transfer pumping operations. Design provisions may include temporary shielding remotely installed and/or remote operations,

A requirement for routine maintenance of radioactively contaminated equipment and equipment in radiation zones is highly undesirable. The design of the RAPID mitigation system shall provide for a 5 year operating life, and shall not require planned replacement of any components during that life. Assume that repair of a transfer pump that has failed in operation is not feasible. This does not preclude the performance of routine, or post transfer operations of very low, or no dose consequence that would extend the life of the RAPID system's hardware. Provision shall be made within the RAPID system design for replacement of ex-tank components that have failed in-service (e.g. control valves, valve operators, sensing elements, gauges). 
HNF-3885

Rev. 0

Feb. 24, 1999

Waste

4.2.1.1 The NGTP shall be capable of pumping fluids with specific gravities (SG) ranging between 1.0 and 1.7 , with viscosity values ranging between 0.55 600 centipoise (CP) at 50 per second shear rate (Reference B).

4.2.1.2 The solids intrinsic to the tank waste have a density of $2.0-2.2 \mathrm{~g} / \mathrm{cc}$ (Reference C). The bulk densities of the convective waste at tank temperatures range from 1.54 to $1.75 \mathrm{~g} / \mathrm{cc}$ (Reference $\mathrm{D}$. See also for chemical composition of the SY-101 waste.).

4.2.1.3 Waste temperatures within SY-101 range between $47.2^{\circ} \mathrm{C}\left(117^{\circ} \mathrm{F}\right)$ and $54.5^{\circ} \mathrm{C}\left(130^{\circ} \mathrm{F}\right.$ ) (maximum per the Authorization Basis, Reference $\left.\mathrm{E}\right)$, with a mean value of $50^{\circ} \mathrm{C}\left(122^{\circ} \mathrm{F}\right)$.

4.2.1.4 Temperatures of the diluted waste should be between 43.3 and $54.4^{\circ} \mathrm{C}$ $\left(110\right.$ and $\left.130^{\circ} \mathrm{F}\right)$ during transfers.

4.2.2.1 As a minimum, the pump provided must be capable of transferring 380 $570 \mathrm{~m}^{3}(100,000-150,000$ gallons) of waste (see paragraph 4.3.1.6) with its associated dilution water (nominal combined volume of waste and dilulent is $760-1140 \mathrm{~m}^{3}$ ) out of SY-101, to SY-102. The transfer must be completed in less than 20 days.

4.2.2.2 The PPP design shall locate the transfer pump's suction bell 0.92 to $4.6 \mathrm{~m}$ ( 3 to $15 \mathrm{ft}$ ) above the bottom of SY-101.

\section{Prefabricated Pump Pit}

The design of the PPP shall provide a drain and seal loop back to the waste tank capable of draining 20 gallons a minute back to tank without plugging, or capable of being unplugged. The seal loop fluid shall be environmentally and waste compatible.

\subsubsection{Transfer Line and Drop Leg}

4.2.4.1 The minimum diluted waste transfer line velocities shall not be less than $1.8 \mathrm{~m} / \mathrm{sec}(6 \mathrm{ft} / \mathrm{sec})$. 
HNF-3885

Rev. 0

Feb. 24, 1999

4.2.4.2 The primary piping's minimum bend radius (at centerline) outside the PPP shall not be less than 5 pipe diameters.

4.2.4.3 The drop leg design shall discharge at an elevation approximately $4 \mathrm{~m}$ (160 in) above the bottom of the SY-102 tank.

4.2.5 Instrumentation

4.2.5.1 Instrumentation shall be selected ensuring that measured properties are within $30-70 \%$ of the instrument span during normal system operation.

4.2.5.2 All instrumentation shall be designed to accommodate simple in-situ operability or functional testing.

4.2.5.3 The design shall include provision for isolation of sensing lines where applicable.

\subsubsection{Infrastructure}

4.2.6.1 Electrical

4.2.6.1.1 A minimum of $160 \mathrm{amps}$, of $480 \mathrm{~V}, 3$ phase power shall be supplied to the transfer pumps VFD enclosure, located outside the farm in the MCC building, 241-SY-272.

4.2.6.1.2 20 Amps of $120 \mathrm{~V}$, single phase control power supplied to the RAPID Mitigation systems control console. The design for provision of power/monitoring of the leak detectors installed in Riser 007 of SY-101, and the drop leg location of SY-102 shall be completed as part of the control system design.

\subsubsection{Water}

4.2.6.2.1 Infrastructure upgrades shall provide a water supply sufficient to support a $380-570 \mathrm{~m}^{3}$ ( $100,000-150,000$ gallon) batch transfer of waste from SY-101, and for post transfer line and pump flushing at the conclusion of pumping.

4.2.6.2.2 The design of the dilution/flush water system shall ensure that in the event of a component failure or an operational discrepancy, no more than 7570 liters (2000 gallons) of water could be added to either SY-101 or 102. 
HNF-3885

Rev. 0

Feb. 24, 1999

4.2.6.2.3 Requirements for flush and dilution water flow rates are identified in the RAPID system Process Fiow Diagram (see Appendix C).

4.2.6.2.4 Water supplied by the water system for waste dilution shall be at $120 \pm 10^{\circ} \mathrm{F}$.

TECHNICAL DESIGN REQUIREMENTS, CONSTRAINTS, AND CRITERIA

4.3.1 System

4.3.1.1 Deployment of the RAPID mitigation system should not preclude operation, or replacement of the mixer pump installed in SY-101's central pump pit, or the transfer pump installed in SY-102.

4.3.1.2 The design of the RAPID mitigation system shall allow for the installation of its hardware with minimum dose consequence.

4.3.1.3 Design of the RAPID must be completed on a schedule that will allow deployment of the system in time to complete an initial transfer from SY101 by September 24, 1999.

4.3.1.4 The RAPID system is intended for use on a batch transfer basis, with the dedicated transfer line and pump flushed following the completion of a waste transfer.

4.3.1.5 The use of automatic/remote controls shall be minimized to the maximum extent practicable both to minimize training requirements, and to minimize the number of components/interface requirements that could compromise the system's operating reliability.

4.3.1.6 The control valves and associated process piping provided as part of the pump-PPP assembly shall provide for the following system operating configurations:

4.3.1.6.1 In-line dilution: Piping, and control valves shall:

4.3.1.6.1.1 allow $100 \%$ dilution water supply to the pump suction at start-up.

4.3.1.6.1.2 ensure instantaneous SY-101 waste transfer flow rates (in seconds) do not exceed 3 times dilution water flow rates.

4.3.1.6.1.3 provide an adjustable lower interlock/alarm limit on dilution water flow.

4.3.1.6.2 Internal Flush: This configuration of piping and control valves shall provide for an internal flush of the transfer pump using heated, raw water controlled within the transfer pump/PPP interface. 
HNF-3885

Rev. 0

Feb. 24, 1999

4.3.1.6.3 Transfer Line Flush: This configuration shall provide for a decontamination flush of the transfer lines using heated raw water to lower radiation fields in regions surrounding the transfer line after a batch transfer of waste has been completed. The transfer pump, including pump flush and dilution lines are isolated from the flush water to allow for more effective flush of the transfer lines and a more accurate accounting of the total water addition to SY-102.

4.3.1.6.4 Transfer line Preheat: This configuration will allow the transfer line to be preheated before transfer of the waste using heated water.

4.3.1.7 The design of the transfer pump and associated discharge "leg" shall ensure that the pump will not be subject to air binding during normal operation when pumping fluid media. Provisions for and the methods of clearing an "air bound" pump shall be explicitly identified in design media.

4.3.1.8 The design shall enable an adjustable upper limit on transfer pump speed.

4.3.1.9 Ensure adequate redundancy in design and spares so that the system can accommodate without damage to the operators, tank farm, or project goals, equipment failures that may occur.

4.3.1.10 A D \& D Plan shall be prepared as part of the RAPID system design.

4.3.1.11 Temperature extremes are identified in the BIO. Design operating temperatures for the RAPID system are $(-) 7$ to $38^{\circ} \mathrm{C}\left(20-100^{\circ} \mathrm{F}\right)$.

4.3.1.12 All environmental load conditions are identified in HNF-PRO-097.

\subsubsection{Prefabricated Pump Pit}

The PPP provides for the following:

- Installation of the transfer pump into Tank 241-SY-101's Riser 007,

- incorporates shielding to reduce radiation dose fields in operator accessed regions around the riser,

- fulfills a confinement function (sized in accordance with the authorization basis requirements for minimum and maximum pit size) in the case of a spray leak at the mechanical connection of the transfer pump to the transfer and flush lines,

- contains control valves necessary to accomplish remote decontamination and flushing of waste transfer lines and pump internals,

- and accommodates the electrical feed throughs necessary to supply power and allow monitoring and control of transfer components installed in the riser, 


$$
\text { HNF-3885 }
$$

Rev. 0

Feb. 24, 1999

- provides a drain back to the tank

4.3.2.1 Pump Mounting

4.3.2.1.1 The PPP shall be isolated from the SY-101 tank dome space. The NFPA Hazardous (classified) locations within the PPP is classified as "nonclassified" in accordance with the Safety Assessment (Reference F), and in accordance with the guidance of the Flammable Gas Equipment Advisory Board (see meeting minutes in Appendix B). Below the PPP, the pump design must meet the requirements for a Class 1, Div 1, Group B environment.

4.3.2.1.2 The PPP shall provide for mounting of the transfer pump in a $106.68-\mathrm{cm}$ (42") diameter tank riser. A survey shall be performed to determine the riser's as-built dimensions that shall be incorporated into an as-built drawing. A sketch of the transfer pump's mounting flange is included in Appendix D.

4.3.2.1.3 The PPP's maximum diameter below the mating flange shall not exceed $101.6 \mathrm{~cm}(40 ")$.

4.3.2.1.4 The overall length of the PPP shall not extend below the junction of the primary and secondary tank walls.

4.3.2.1.5 The design of the PPP shall not amplify the pump resonant frequencies.

4.3.2.1.6 The design shall allow for the removal/replacement of a failed transfer pump without removal of the PPP.

4.3.2.1.7 The design of the PPP assembly must provide for the mechanical/electrical feed throughs. Design of the feed throughs shall not preclude replacement of a failed transfer pump while the PPP assembly is installed in the waste tank.

4.3.2.1.8 The PPP assembly includes piping and control valves necessary to allow flushing of the transfer line, pump bearings, and pump internals.

4.3.2.1.9 Piping and valves shall be configured to allow manual control of dilution water supply to the transfer pump.

4.3.2.1.10 Connections to the transfer pump shall be made via remote connection or methods with short radiation exposure durations during field installation and removal.

4.3.2.1.11 The piping design within the PPP shall preclude the accumulation of solids after a pump shutdown. 
HNF-3885

Rev. 0

Feb. 24, 1999

\subsubsection{Seal Loop/Drain}

4.3.2.2.1 During routine operations, the seal loop shall provide a water seal, isolating the internal environs of the PPP from the waste tank's dome space. Nominal tank dome space operating pressure is 1-4 inWC vacuum (maximum 6 inWC).

4.3.2.2.2 A method for freeze protection, remote monitoring and filling of the seal loop shall be provided.

4.3.2.2.3 The drain design shall allow a depth accumulation of at least $1.27-\mathrm{cm}$ $\left(1 / 2^{\prime \prime}\right)$ of liquid in the bottom of the pre-fabricated pump pit prior to draining to tank to allow sufficient accumulation of liquid for activation of the leak detectors. The design shall allow for complete drainage from the PPP after a leak detector alarm per the requirements of WAC 173-303640.

4.3.2.2.4 The design of the PPP assembly shall incorporate a Safety Class leak detector.

4.3.2.2.5 Those portions of the PPP that function as a secondary containment barrier to the primary piping must comply with the WAC 173-303-640 (4) "Containment and detection of releases" requirements.

\subsubsection{Decontamination Spray Ring}

4.3.2.3.1 A high-pressure spray ring (maximum capacity $20,684 \mathrm{kPa}(3000 \mathrm{psi}$ ) and supply line shall be provided as part of the PPP design.

4.3.2.3.2 The ring shall have nozzles mounted that provide $360^{\circ}$ of coverage directed at the pump centerline.

4.3.2.3.3 The spray ring shall be mounted on the exterior bottom surface of the PPP.

4.3.2.3.4 Spray nozzle design and orientation shall be selected to minimize the formation of aerosols and provide maximum cleaning.

4.3.2.3.5 Spray ring piping shall terminate outside of the PPP.

\subsubsection{Transfer System (PPP) Cover}

4.3.2.4.1 The design of the PPP shall isolate equipment contained within the interior of the PPP from the tank dome space environment.

4.3.2.4.2 The design of the PPP shall ensure that new spurious air-ingress paths into the tank dome space are not created. This seal(s) must withstand 
HNF-3885

Rev. 0

Feb. 24, 1999

the (-) 6 inWC differential pressure, the maximum vacuum generated by the existing primary ventilation system.

4.3.2.4.3 The design shall ensure that a confinement boundary that prevents the migration of radioactive contamination and prevents communication between the PPP and the environs is established.

4.3.2.4.4 The transfer system (PPP) cover must allow for replacement of the transfer pump without removing the PPP. The safety class function of the cover is to provide a tortuous path boundary between the waste tank dome space and the environs in the event of a waste line spray leak.

4.3.2.4.5 The transfer system cover shall also provide a non-sparking access port for vapor space monitoring of flammable gas concentrations within the closed PPP assembly.

4.3.2.4.6 The design of the PPP and transfer system cover shall preclude the buildup of flammable gasses.

\subsubsection{Transmitted Loads}

4.3.2.5.1 Loads transferred to the riser/tank dome via the PPP assembly, at any time during the PPP's installation in the tank, including installation, pump operation and transfer, shall not damage the tank or riser (see Section 4.5 below). The design and installation procedures shall ensure that drop loads that could occur during installation in the riser are covered by the BIO.

4.3.2.5.2 The transfer pump installation, support load frame, and the existing tank structures (riser and tank dome) shall not be damaged or exceed allowable stresses when subjected to the maximum loads and any cyclic loads that occur from operation of the transfer pump or the mixer pump. Cyclic loads shall address the effect of the mixer pump operation on the transfer pump and the normal cyclic loading caused by operation of the transfer pump. The transfer pump shall not be damaged or exceed allowable stresses when subjected to cyclic loads caused by operation of the mixer pump.

\subsubsection{Transfer Line}

\subsubsection{Primary Piping}

4.3.3.1.1 The primary transfer piping is rated as general service, and provides no safety function.

4.3.3.1.2 The inner pipe shall be designed and fabricated in accordance with the provisions of ASME B31.3 (use latest version). In no instance may the 


$$
\begin{gathered}
\text { HNF-3885 } \\
\text { Rev. } 0
\end{gathered}
$$

Feb. 24, 1999

rated working pressure of the newly installed piping be less than that prescribed by the M-25 Piping Code as modified by B-101-C3 (230 psig).

4.3.3.1.3 Connections of the inner pipe to pump and drop leg connections may be made via mechanical methods.

4.3.3.1.4 For welded connections, welders and welding procedures shall be qualified in accordance with ASME B\&PV Code, Section IX.

4.3.3.2 Encasement Piping

4.3.3.2.1 The transfer line encasement is a Safety Class component.

4.3.3.2.2 The encasement piping shall be designed and fabricated in accordance with the provisions of ASME B31.3, with additional inspection requirements as identified in ASME B \& PVC, Section V, and quality assurance requirements per ASME NQA- 1 . In no instance may the rated working pressure of the newly installed piping be less than that prescribed by the M-26 Piping Code as modified by B-101-C3 (60 psig).

4.3.3.2.3 A manner for objectively verifying the integrity of the barrier formed by the encasement piping while connected to the transfer pump and drop leg after installation in the field shall be provided by the design (pressure test).

\subsubsection{Transfer Line Assembly}

4.3.3.3.1 Spacers or shims used to locate the primary piping shall not impede the gravity flow of liquid within the encasement piping to leak detection elements.

4.3.3.3.2 Jumper design (if applicable) and fabrication shall be compatible with existing design (Reference $\mathrm{J}$ ) criteria.

\subsubsection{Leak Detectors}

4.3.3.4.1 RAPID system leak detectors shall be provided at all low points. The number of low points shall be minimized to the extent practicable.

4.3.3.4.2 A leak detector system that complies with WAC 173.303 requirements shall be provided for the transfer line and/or transfer associated structure(s).

4.3.3.5 Heat Trace

4.3.3.5.1 The transfer line piping shall be provided with thermostatically controlled heat trace. 


\section{HNF-3885}

Rev. 0

Feb. 24, 1999

\subsubsection{Drop Leg}

4.3.3.6.1 Drop leg discharge to the tank shall be accomplished so as to maximize the horizontal component of the stream velocity to facilitate mixing of the discharge stream with the contents of SY-102.

4.3.3.6.2 Drop leg discharge configuration shall be designed to:

4.3.6.6.2.1 minimize the restriction to transfer system flow rates,

4.3.6.6.2.2 prevent the accumulation of solids,

4.3.6.6.2.3 minimize the potential for plugging.

4.3.4 Control and Instrumentation

4.3.4.1 Control

4.3.4.1.1 Operator Interface: The transfer pump controls shall be limited to an onoff key switch at the DACS transfer pump panel and an emergency trip at the Farm control panel.

4.3.4.1.2 Transfer Pump Status: Operating lights shall be provided that indicate the status (ON/OFF) of the transfer pump at both transfer pump control locations.

4.3.4.1.3 Engineering Interface: The design of the RAPID System shall allow for engineering directed alteration of the transfer pump's variable frequency drive settings.

4.3.4.1.4 Water Skid Flush/Dilution Pump(s) Status: Operating lights shall be provided as part of the water skid that indicate the status (ON/OFF) for each of the water skid pumps.

4.3.4.1.5 The Rapid system's piping configuration is to be administratively controlled. All valve operation performed to reconfigure the system is to be performed manually to the maximum extent practicable.

4.3.4.2 Instrumentation

4.3.4.2.1 A transfer system control panel (remote) will be installed in DACS Trailer.

4.3.4.2.2 The transfer system will not interface with the DACS.

4.3.4.2.3 The use of installed spares shall be considered as part of the design. 


\section{HNF-3885}

Rev. 0

Feb. 24, 1999

4.3.4.2.4 Transfer Line Pressure: Transfer line pressure shall be monitored and displayed.

4.3.4.2.5 Transfer Line Flow: Flows of diluted waste and transfer line flush water shall be monitored and displayed.

4.3.4.2.6 Transfer Line Temperature: Transfer line waste temperatures shall be displayed.

4.3.4.2.7 Dilution Line Flow: Dilution line flow rates shall be displayed.

4.3.4.2.8 Water Skid Tank Temperature: Water temperatures in the skid water tank shall be displayed.

4.3.4.2.9 Service Water Totalizer: The raw water supply shall be equipped with a safety significant flow totalizer that will indicate total water supplied to the RAPID System.

4.3.4.2.10 Transfer System Leak Detection: Intrinsically safe leak detectors shall be installed in any low points. Leak detectors shall be set to alarm at 1.27 $\mathrm{cm}(1 / 2)$ liquid level. Both visual and audible indication of alarm shall be provided.

4.3.4.2.11 Water Skid Flush/Dilution Pump Pressure: The discharge pressure of the water skid flush/dilution water pump(s) shall be displayed.

4.3.4.2.12 Water Skid Flush/Dilution Pump Flow: The flow rate from the water skid flush/dilution water pump(s) shall be displayed.

4.3.4.2.13 Water Skid Water Flow Totalizer: The water skid discharge piping shall be equipped with a flow totalizer that will indicate total water supplied discharged from the flush/dilution water pumps.

4.3.4.2.14 Sensing elements shall readout both locally and remotely. Minimum requirements are defined in Table 4-1. Columns in the table are defined below:

- PPP: An indicator panel at the PPP, within view of the operator controlling dilution line valve settings. Location of the panel will consider ALARA principles.

- Remote: An indicator panel within the Data Acquisition and Control System (DACS) trailer near the transfer pump-operating console.

- Local: Local displays shall be located at or near the sensing element installation location.

- Skid: An indicator panel located on the portable water skid. 
HNF-3885

Rev. 0

Feb. 24, 1999

TABLE 4-1

INSTRUMENTATION/ALARM INDICATION LOCATION

\begin{tabular}{|l|c|c|c|c|}
\hline & PPP & Remote & Local & Skid \\
\hline INSTRUMENT READOUT & & & & \\
\hline Transfer Line Pressure & $\mathrm{X}$ & & & \\
\hline Transfer Line Flow & $\mathrm{X}$ & $\mathrm{X}$ & & \\
\hline Transfer Line Temperature & $\mathrm{X}$ & $\mathrm{X}$ & & \\
\hline Dilution Line Flow & $\mathrm{X}$ & $\mathrm{X}$ & & \\
\hline Transfer Pump Operation (ON/OFF) & $\mathrm{X}$ & $\mathrm{X}$ & & \\
\hline Emergency Trip Transfer Pump & $\mathrm{X}$ & & & \\
\hline Service Water Flow Totalizer & & & $\mathrm{X}$ & \\
\hline Water Skid Tank Temperature & & & & $\mathrm{X}$ \\
\hline Water Skid Flush/Dilution Pump Pressure & & & & $\mathrm{X}$ \\
\hline Water Skid Flush/Dilution Pump Flow & & & & $\mathrm{X}$ \\
\hline Water Skid Water Flow Totalizer & & & & $\mathrm{X}$ \\
\hline Water Skid Pump Run Indication & & & & $\mathrm{X}$ \\
\hline & & & & \\
\hline ALARMS & & & & \\
\hline Leak Detection & $\mathrm{X}$ & $\mathrm{X}$ & $\mathrm{X}$ & \\
\hline Low Dilution Line Temperature & $\mathrm{X}$ & $\mathrm{X}$ & & \\
\hline Low Seal Loop Level & $\mathrm{X}$ & $\mathrm{X}$ & & \\
\hline Flush Water Isolation Pressure & $\mathrm{X}$ & $\mathrm{X}$ & & $\mathrm{X}$ \\
\hline Water Skid Tank High Level & & & & $\mathrm{X}$ \\
\hline Water Skid Tank Low Level & & & & $\mathrm{X}$ \\
\hline
\end{tabular}

4.3.5 Alarms

4.3.5.1 Leak Detection: The RAPID System shall be provided with both visual and audible indication (both local and remote locations) that a leak has been detected in any of the RAPID system dedicated leak detectors.

4.3.5.2 Low Dilution Line Temperature: Indicates in-line dilution of waste may be having a detrimental effect on waste temperature during transfer, and may result in plugging of the transfer line. Requires operator evaluation.

4.3.5.3 Low Seal Loop Level: Indicates liquid level low in the PPP seal loop.

4.3.5.4 Flush (Transfer Line and Pump Cavity) Water Isolation Pressure: A pressure switch shall be provided that will trigger both audible and visual indication of a loss of pressure boundary integrity at the waste/raw water interface.

4.3.5.5 Water Skid Tank High Level: A level alarm shall be provided that gives visual and audible indication of a high water level in the water skid flush/dilution water holding tank. 


\section{HNF-3885}

Rev. 0

Feb. 24, 1999

4.3.5.6 Water Skid Tank Low Level: A level alarm shall be provided that gives visual and audible indication of a low water level in the water skid flush/dilution water holding tank.

\subsubsection{Interlocks}

4.3.6.1 Dilution Water Supply: An interlock shall be provided that stops transfer pump operations on high or low dilution water flow rates.

4.3.6.2 Transfer Line: A feature to prevent an inadvertent water addition to the waste tanks shall be designed.

4.3.7 Infrastructure

4.3.7.1 Water

4.3.7.1.1 Cross contamination control is required to prevent the contamination of the service water supply source from waste in the transfer pump piping/transfer lines.

4.3.7.1.2 The design of the dilution/fiush water supply system shall incorporate safety class features that will prevent the contamination of the water supply by tank waste.

4.3.7.1.3 Heated water shall be supplied to the PPP for use as dilution water by the transfer line.

4.3.7.1.4 A skid mounted totalizer and flow meter (GPM) shall be included in the raw water system infrastructure upgrades.

4.3.7.1.5 Water supply piping shall be designed and constructed in accordance with the provisions of ANSI B31.3.

4.3.7.1.6 Provision shall be made for a flush of the transfer line in the event of a loss of heated raw water.

4.3.7.2 Electrical

4.3.7.2.1 Electrical power shall be routed to the PPP in accordance with National Electrical Code requirements.

4.3.7.2.2 Any power or control wiring that is not permanently installed in underground Trendways or buried conduit shall have receptacles, plugs, and connectors to allow removal after use without tools of any kind. (e.g.if a power cord is run temporarily on the ground, the above ground portion 
HNF-3885

Rev. 0

Feb. 24, 1999

should have welding type connectors at each end, so the cord can be easily disconnected and removed when not in service.)

Installation Hardware

The PPP and drop leg assemblies shall be provided with lifting attachment points. These attachment points shall be used during installation of the assembly into position. Lifting attachment points shall be designed such that the assembly can be adjusted to hang plumb within $\pm 2.54 \mathrm{~cm}$ (1") over its length during installation in the tank with a crane. Below-the-hook lifting hardware, if required, shall be designed and provided with the PPP assembly. Design shall be in accordance with ANSI B30.20, and DOE-RL-92-36, Hanford Site Hoisting and Rigging Manual.

MATERIALS

4.4.1 Selection of materials shall consider operations, maintenance, and decontamination and decommissioning in addition to ensuring compatibility with interfacing components and environments.

4.4.2 All piping within the PPP shall be 304L Series Stainless Steel (ASTM A312) to minimize corrosion and facilitate decontamination.

4.4.3 Each major component fabrication specification or drawing shall specify the appropriate standard to be used for material procurement.

4.4.4 The use of hazardous materials (e.g., lead) shall be minimized and specifically identified in design media. The use of organic based lubricants in components or assemblies of the RAPID System that must be placed in the waste tanks shall be avoided. If lubricants must be used, special consideration shall be given to ensure that the lubricant will not leak into the tank.

4.4.5 The drop leg assembly shall be fabricated from $300 \mathrm{~L}$ series stainless steel to facilitate decontamination during removal, and minimize its potential for corrosion in the tank.

4.4.6 Welding of the drop leg shall be in accordance with AWS D1.1 or other recognized equivalent.

4.4.7 To the maximum extent practical the design shall use existing parts. 
HNF-3885

Rev. 0

Feb. 24, 1999

The allowable tank riser loading precludes direct mounting of the PPP and transfer pump. A load frame and associated foundation designed to transmit PPP associated loads to the tank overburden must be provided while allowing direct connection between the PPP and riser flange to ensure waste tank ventilation confinement is maintained.

The applied loads (dead weight, pressure, vibration, seismic, wind, etc.) and load combinations for each component and structure shall be defined in a structural design criteria (SDC) document, reviewed and approved by the Design Review Committee. The natural phenomena loadings shall be a function of the safety classes of the SSCs and evaluated in accordance with HNF-PRO-097 and DOE-6430.1A.

The SDC shall also provide codes and standards used to evaluate and qualify the SSCs of the waste transfer system. The application of those codes and the fulfillment of their requirements shall be documented in a design compliance matrix prepared as part of the design.

MECHANICAL ENGINEERING

The RAPID Mitigation System could include a significant number of mechanical components, including pumps, piping, valves, and hydraulic/pneumatic accumulators. Consensus codes and standards applicable to the system design shall be appropriately applied during design. The application of those codes and the fulfillment of their requirements shall be documented in a design compliance matrix prepared as part of the design.

\section{ELECTRICAL, INSTRUMENTATION AND CONTROLS}

The RAPID Mitigation System will include a significant number of instrumentation and electrical components. Consensus codes and standards applicable to the system design shall be appropriately applied during design. The application of those codes and the fulfillment of their requirements shall be documented in a design compliance matrix prepared as part of the design. 
HNF-3885

Rev. 0

Feb. 24, 1999

4.8

4.9

4.10

4.10 .1

4.10 .2

4.10 .3

4.10.4

\section{SAFETY}

The Authorization Basis for this design is split between the Los Alamos National Laboratory's (LANL) Safety Assessment (SA)(Reference F), and the Tank Waste Retrieval Systems (TWRS) Basis for Interim Operation (BIO) (Reference E). Efforts are currently underway to resolve differences between the two.

The LANL SA presentiy prescribes the NFPA hazardous classification environment in and around SY-101. The tank's annulus and above grade zones are presently nonclassified per the NFPA guidelines. The dome space within 3 feet of the waste is classified as Class 1, Div 1, Group B. The remainder is Class 1, Div 2, Group B. Within the waste is nonclassified.

\section{RADIATION AND NUCLEAR CONTROL}

The RAPID System design shall be performed in accordance with the requirements of 10 CFR 835 and HSRCM-1, Hanford Site Radiological Control Manual, and DOE 6430.1A, ensuring that operator and maintenance dose consequence associated with the RAPID Systems Installation/Operation/Maintenance and Decommissioning remains As Low As Reasonably Achievable (ALARA). The following procedures HNF-PRO-1621, "ALARA Decision-Making Methods" and HNF-PRO1622, "Radiological Design Review Process" will be used to guide the optimization and subsequent application of radiological source term reduction techniques.

The RAPID System design shall limit radiation field dose rates per the design objectives stated in 10CFR835.1002 paragraph (b).

\section{HUMAN ENGINEERING}

Process variable displays shall be located within view of individuals operating system control elements.

Minimize the need for operator action in the event of unexpected conditions (transients).

Simplify system design to rely primarily on direct operator control rather than on automatic control.

Control system design should minimize the level of training required for safe operation. 
HNF-3885

Rev. 0

Feb. 24, 1999

4.10.5 Control system design should minimize the amount of coordination required between operators in locations distant from one another.

4.10.6 Layout of displays, labeling of components, and control orientation should be readable and adhere to the guidelines of MIL-STD-1472C, "Human Engineering Design Criteria for Military Systems, Equipment, and Facilities", EPRI NP-3659, "Human Factors Guide for Nuclear Power Plant Control Room," to the extent practical. The requirements of HNFIP-0842, Volume IV, Section 4.14, "Tank Farm Operations Equipment Labeling and Master Equipment List Control" shall be met.

4.10.7 The design of the RAPID system should follow the guidance of UCRL15673, "Human Factors Design Guidelines for Maintainability of DOE Nuclear Facilities."

4.10.8 Personnel Training and Staffing requirements are identified in HNF-3824, "Tank 241-SY-101 Surface Level Rise Remediation Project Plan."

LOGISTICS

Construction and operation of the RAPID Mitigation System are not expected to result in the generation of any waste not already addressed within existing guidelines, procedures, and permits. Waste generated during decommissioning shall be addressed in the $D \& D$ plan.

4.12 PROJECT INTERFACES

RAPID system interface requirements are summarily identified in Table 4-2.

4.12.1 Waste Tanks

The top of SY-101 Riser $007106.68 \mathrm{~cm}$ (42") diameter flange face is at an elevation of $204.9 \mathrm{~m}$ ( $672.24 \mathrm{ft}$ ), approximately $5.08 \mathrm{~cm}$ (2 inches) above the ground. The flange includes $6-2.22 \mathrm{~cm}\left(7 / 8^{\prime \prime}\right)$ diameter holes on a $118.11 \mathrm{~cm} \mathrm{(46} \mathrm{1/2")} \mathrm{diameter} \mathrm{bolt} \mathrm{circle.}$

The top of SY-102 Riser $007106.68 \mathrm{~cm}$ (42") diameter flange face is at an elevation of $204.8 \mathrm{~m}$ ( $672.01 \mathrm{ft})$, approximately $5.08 \mathrm{~cm}$ ( 2 inches) above the ground. The flange includes $6-2.22 \mathrm{~cm}(7 / 8 ")$ diameter holes on a $118.11 \mathrm{~cm}(461 / 2$ ") diameter bolt circle. 
Rev. 0

Feb. 24, 1999

\subsubsection{Water}

All water for the 200 Area is supplied from the Hanford Site export water system. Export water is defined as water pumped from the Hanford Site reservoir to reservoirs located in the 200 East and 200 West Areas.

Water is distributed throughout the area by two separate systems, the raw water system and the sanitary water system. Raw water is untreated and is used principally for cooling, flushing, and dilution systems. Sanitary water is treated (filtered, purified, etc.) and is used for drinking and sanitary facilities.

All water supply piping that has the potential for contacting other water or radioactively contaminated liquids is protected with backflow preventers. In addition, to monitor raw water usage in TWRS facilities, flow totalizers have been installed.

TABLE 4-2

RAPID SYSTEM INTERFACE TABLE

\begin{tabular}{|c|c|c|c|c|c|c|c|c|c|c|c|c|c|}
\hline & 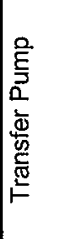 & $\frac{\alpha}{\alpha}$ & 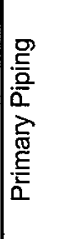 & 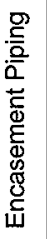 & 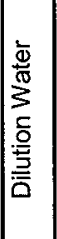 & 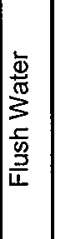 & 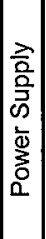 & 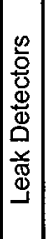 & $\begin{array}{l}\frac{0}{0} \\
\frac{1}{1} \\
\frac{0}{0} \\
0\end{array}$ & 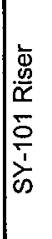 & 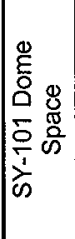 & 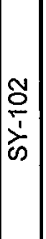 & $\mid$ \\
\hline Transfer Pump & 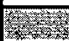 & $x$ & $x$ & & $x$ & $x$ & $x$ & & & & $x$ & & \\
\hline PPP & $\mathrm{x}$ & 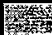 & $\mathrm{X}$ & $\bar{x}$ & $\mathrm{X}$ & $\bar{x}$ & $\mathrm{x}$ & $x$ & & $\mathrm{x}$ & $x$ & & \\
\hline Primary Piping & $x$ & $x$ & Fin & $x$ & & $\mathrm{x}$ & & & $x$ & & & $x$ & \\
\hline Encasement Piping & & $\bar{x}$ & $x$ & 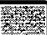 & & & & $x$ & $\bar{x}$ & & & $\mathrm{x}$ & $x$ \\
\hline Dilution Water & $x$ & $\bar{x}$ & & & 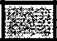 & $\mathrm{x}$ & & & & & & $\mathrm{x}$ & \\
\hline Flush Water & $\bar{x}$ & $\bar{x}$ & $x$ & & $x$ & 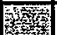 & & & $\mathrm{x}$ & & & $\mathrm{x}$ & \\
\hline Power Supply & $\mathrm{X}$ & $x$ & & & & & 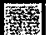 & $\mathrm{X}$ & & & & & \\
\hline Leak Detectors & & $x$ & & $\mathrm{x}$ & & & $\mathrm{x}$ & 型器 & & & & $x$ & \\
\hline Drop Leg & & & $\bar{x}$ & $\bar{x}$ & & $\mathrm{x}$ & & & 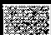 & & & $\mathrm{X}$ & \\
\hline SY-101 Riser & & $x$ & & & & & & & & 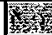 & $x$ & & \\
\hline SY-101 Dome Space & $x$ & $x$ & & & & & & & & $x$ & 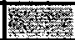 & & \\
\hline SY-102 & & & $x$ & $x$ & $x$ & $x$ & & $x$ & $x$ & & & 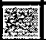 & \\
\hline$D \& D$ & & & & $x$ & & & & & & & & & 靠 \\
\hline
\end{tabular}


HNF-3885

Rev. 0

Feb. 24, 1999

4.12.3 Electrical

Substation 242-S supplies power to Motor Control Center SY272-EDSMCC-003 at $480 \mathrm{~V}, 3$ phase. This MCC provides power to the existing SY-101 Mixer Pump through a variable frequency drive located in the MCC Building. A new compartment in SY272-EDS-MCC-003 will be utilized to provide power through a new $125 \mathrm{HP}, 480 \mathrm{~V}$, VFD to the SY101 New Generation Transfer Pump. The pump is a $60 \mathrm{HP}$ unit that due to its overspeed capabilities and operational parameters requires the larger drive noted above. The drive will be located in the MCC Building. The circuit to the motor will include an isolation disconnect at the output of the drive and one within sight of the PPP. The circuit will utilize existing wireways (conduits and trench) where possible. Some additional wireways will be required to complete the circuit to the pump.

4.13

SECURITY

NOT APPLICABLE.

\subsection{QUALIFICATION}

Qualification of the RAPID Mitigation System design shall be accomplished through a combination of formal design verification and verification/acceptance testing. 
HNF-3885

Rev. 0

Feb. 24, 1999

The "quality" management system for this activity is designed to achieve project control and meet our customer's quality requirements as specified in 10 CFR 830.120, "Quality Assurance." Additional customer quality requirements are derived from the Hanford Federal Facility Agreement and Consent Order (Tri-Party Agreement) (Ecology et al. 1994). These quality requirements are transmitted to this activity through FDH-MP0599, the FDH Quality Assurance Program Description, which identifies the guidance criteria to be used by all Project Hanford Management Contractors.

The interpretive authority for the customer's quality requirements is the QA Center of Expertise (COE). The QA COE has described the plan to achieve the customer's quality requirements in WHD-SP-1131, Quality Assurance Program and Implementation Plan.

This activity's quality assurance policies and requirements is described in HNF-IP-0842, Volume XI, Sec. 1.1, TWRS Quality Assurance Program Plan (QAPP) document. This QAPP includes an "Implementation Matrix" which identifies (1) the ten major elements of the requirements from DOE Order $5700.6 \mathrm{C}$ and $10 \mathrm{CFR} 830.120$, (2) the sub-elements for each major element as specified in the Fluor Daniel Hanford Quality Assurance Program Description (HNF-MP-599), and (3) the associated implementation documents cited in the matrix constitute the TWRS approach for achieving the requirements delineated in the FDH QAPD.

5.1

5.1 .1

5.1 .2

\section{INSPECTIONS}

Cleanliness requirements for the fabrication and installation of RAPID system assemblies shall be specified by their design. Cleanliness inspections shall be performed at the completion of fabrication, and again at the end of any acceptance testing performed prior to installation in the field. Dirt, oil residue, liquids, metal chips, or other forms of contamination shall be removed using approved cleaning methods.

Requirements for the permanent marking of RAPID System components and assemblies shall be specified in design media. As a minimum, marking requirements shall provide a tie between hardware and design drawings.

\section{TEST AND EXAMINATIONS}

5.2.1 The transfer line primary and encasement piping shall be pressure tested in accordance with ASME B31.3. 
HNF-3885

Rev. 0

Feb. 24, 1999

5.2.2 Performance testing shall be specified for the pump and operational components within the PPP. Sufficient data shall be obtained to assure satisfactory operation after installation in SY-101.

5.2.3 A run-in test shall be specified. The pump shall be placed in a test fixture and operated at pump design flow rates and pressures for a minimum of 24 hours prior to acceptance by Lockheed Martin Hanford Company or installation in SY-101.

5.2.4 Additional testing to be specified shall include verification of the interface between the RAPID control console and the transfer pump PPP assembly and its associated control valves provided for the various operating configurations identified in paragraph 4.3.1.6. The performance of the dilution system shall be demonstrated via testing.

5.2.5 Verification testing shall be specified for all essential components to ensure their ability to fulfill the form, fit, and function required by the RAPID system design.

6.0

TURNOVER

Requirements for documentation required for turnover of the RAPID system will be described as part of an Acceptance for Beneficial Use listing, included as part of HNF-4044, "Engineering Task Plan for Waste Transfer from Tank 241-SY-101 to 241-SY-102."

\subsection{APPENDICES}

Appendix A Internal Memo

Appendix B FGEAB Meeting Minutes

Appendix $C$ Process Flow Diagram

Appendix D NGTP Flange Interface Drawings

Appendix E Internal Memo (Draft) 
HNF-3885

Rev. 0

Feb. 24, 1999

\section{APPENDIX A}

\section{INTERNAL MEMO}

(FOR INFORMATION ONLY) 
From:

Phone:

Date:

Subject:
Process Control

373-2461

February 11, 1999

ANTICIPATED DYNAMIC VISCOSITY AND SOLIDS

CONCENTRATION OF SLURRIES PRODUCED DURING THE

DILUTION AND TRANSFER OF TANK 241-SY-101 WASTES TO TANK 241-SY-102

To: W. J. Powell S5-13

cc: Distribution

References: (1) Document, "In Situ Rheology and gas Volume in Hanford double-Shell Waste Tanks, PNNL-11296, dated September 1996.

(2) Document, and Physical Properties of Tank 241-SY-101 Waste, PNL10198, dated October 1994.

This memo is issued to constitute a referenceable basis for specifying the Respond and Pump in Days (RAPID) waste transfer system for tank 241-SY-101. Specifically, the questions answered in this memo are as follows:

(1) What is the significance of the specified water dilution ratios for tank 241-SY-101 waste?

(2) What are the volume percent precipitated solids in the resulting slurries?

(3) What are the ranges of dynamic viscosity for these slurries?

(4) What dilution is required to produce a slurry viscosity of $30 \mathrm{cP}$ ?

(1) The volumetric dilution range specified for the RAPID system varies from 2 parts waste to 1 part water to 1 part waste to 2 parts water. The mean dilution ratio is specified as 1 part waste to 1 part water. The low dilution limit is specified due to concerns about the build-up of high salt concentrations in tank 241-SY-102. Some of the 200 West area single-shell tank saltwell wastes possess high concentrations of phosphate. Interim stabilization activities accumulate these wastes in tank 241-SY-102. By limiting the nitrate/nitrite salt concentrations in tank 241-SY-102, the probability of phosphate precipitation will be minimized. The high dilution limit is specified from a desire to limit the impact of tank 241-SY-101 transfer activities on operational double-shell tank volume.

(2) The volume percent precipitated solids contained in the in-situ convective regions of tank $241-\mathrm{SY}-101$ are stated as $5 \%$ to $25 \%$ with a mean of $15 \%$. This corresponds to the solids concentration at $120^{\circ} \mathrm{F}$. During the actual transfer of waste from tank 241-SY-101 to tank $241-\mathrm{SY}-102$, the waste will be in the piping system for only a few seconds. It is prudent to assurne that no dissolution of precipitated solids occurs during slurry transfer. Therefore, the solids concentrations in the transferred waste are diluted proportional to the dilution volume of water. 
Page 2

February 11, 1999

Assuming that tank $241-\mathrm{SY}-101$ waste with 25 volume (vol) $\%$ solids is diluted with water at the low dilution limit, the maximum expected solids concentration in the transfer line is:

$$
[2(25 \mathrm{vol} \%)+1(0 \mathrm{vol} \%)] \div(2+1)=17 \mathrm{vol} \%
$$

Likewise, the mean slurry solids concentration derived the mean value of tank 241-SY-101 convective waste solids concentration and the mean water dilution yields:

$$
[1(15 \mathrm{vol} \%)+1(0 \mathrm{vol} \%)] \div(1+1)=7.5 \mathrm{vol} \%
$$

The resulting slurry solids concentration is the transfer line is expected to range from about 2 vol\% to 17 vol $\%$ with 7.5 vol $\%$ as the mean.

(3) The question of the viscosity of slurries is highly complex and essentially indeterminate. The viscosity and viscosity behavior of many liquids, such as water, is well defined. However, when suspended solids are included in a liquid (i.e., a slurry), no universally known method exists to specify the viscosity of a slurry, even if other physical properties of the slurry are well known. For example, whereas most liquids can be considered Newtonian fluids, most slurries cannot. The only way the viscosity of an actual slurry in a specific application can be positively determined is to measure it in that application. Such a measurement cannot be made in the application of the transfer from tank 241-SY-101.

The best known means of estimating a slurry viscosity from other known slurry parameters is via an "Einstein" type relationship. This relationship can at best be considered as only a rough rule-of-thumb. In a simplified form, this relationship expresses the slurry viscosity as a linear function of the carrier liquid viscosity and an exponential function of the solids loading or slurry density. Some terms are useful to define:

$$
\begin{aligned}
& c=\text { carrier or liquid phase of a slurry } \\
& d=\text { dispersed or solid phase of a slurry } \\
& m=\text { bulk property of a slurry } \\
& \alpha=\text { phase volume fraction in a slurry (dimensionless) } \\
& \rho=\text { phase density of a slurry (units of mass per volume) } \\
& \mu=\text { dynamic viscosity (units of mass per length per time) }
\end{aligned}
$$

HNF-3885

Rev. 0 
Page 3

February 11, 1999

The following relationships apply:

$$
\begin{aligned}
& \alpha_{c}+\alpha_{d}=1 \\
& \rho_{m}=\alpha_{c} \rho_{c}+\alpha_{d} \rho_{d} \\
& \rho_{\infty}=\rho_{m} \text { at infinite dilution, where } \rho_{m}=\rho_{c}
\end{aligned}
$$

$\alpha_{d}$ must be distinguished from the volume fraction of settled solids. Settled solids always contain void volumes occupied by the liquid phase so that the volume fraction of settled solids will be greater than the volume fraction of dispersed solids, AKA true solids.

The desired quantity is the slurry viscosity $\mu_{\mathrm{m}}$. A simplified "Einstein" relationship can then be defined as:

$$
\mu_{m}=\mu_{c} \exp \left[k\left(\frac{\rho_{m}-\rho_{\infty}}{\rho_{\infty}}\right)\right] \quad \text { where "k" is an empirical constant }
$$

Therefore, the slurry viscosity becomes a function of the carrier liquid viscosity and the difference in density between the slurry and its carrier liquid.

To determine the constant in the "Einstein" relation, the value of $\mu_{\mathrm{m}}$ must be known for at least one set of $\mu_{\mathrm{c}}, \rho_{\mathrm{c}}$, and $\rho_{\mathrm{m}}$ values. $\rho_{\mathrm{m}}$ is a value nailed down fairly well for the waste in question. The range of $\rho_{\mathrm{m}}$ values for tank 241-SY-101 convective wastes at $120^{\circ} \mathrm{F}$ is stated as 1.45 to $1.75 \mathrm{gm} / \mathrm{cc}$ with a mean of $1.60 \mathrm{gm} / \mathrm{cc}$. For tank $241-\mathrm{SY}-101$ wastes, the value of $\rho_{\mathrm{c}}$ at any non-infinite dilution is not known with much precision. The only thing that can be positively stated for tank 241-SY-101 waste is that at infinite dilution, $\rho_{\mathrm{m}}=\rho_{\mathrm{c}}=1.0 \mathrm{gm} / \mathrm{cc}$.

References (1) and (2) document viscosity analyses performed on tank 241-SY-101 wastes. Reference (1) reported results from ball rheometer testing in tank 241-SY-101 and Reference (2) investigated material from core 22 taken during Window C. Both references report NonNewtonian, shear-thinning (thixotropic) behavior of the tank wastes.

Analyses documented in Reference (2) looked at parameters of $\rho_{m}$, settled solids density, settled solids volume fraction, filtered solids weight fraction, and viscosity at a $400 \mathrm{sec}^{-1}$ shear rate at a $0,10,20,35$, and $50 \mathrm{vol} \% 2 \mathrm{M} \mathrm{NaOH}$ dilution and 50,70 , and $90^{\circ} \mathrm{C}$. The results indicate that little difference could be noted between $\rho_{\mathrm{m}}$ and the settled solids density at any dilution or temperature. Differences in viscosity, volume percent settled solids, and weight percent filtered solids showed much more variation at differing dilutions and temperatures. In this application, $2 \mathrm{M} \mathrm{NaOH}$ can be considered equivalent to water. 
W. J. Powell

74B50-99-017

Page 4

February 11, 1999

Reference (2) reported a dynamic viscosity of $40 \mathrm{cP}$ at a $400 \mathrm{sec}^{-1}$ shear rate for undiluted waste at $50^{\circ} \mathrm{C}$. Reference (1) reported the following ball rheometer viscosity behavior with an uncertainty factor of 2 (Section 4.1.2):

\begin{tabular}{|l|l|l|l|l|}
\hline Shear rate $\left(\mathrm{sec}^{-1}\right)$ & 1 & 10 & 100 & 400 \\
\hline Viscosity $(\mathrm{cP})$ & $\sim 600$ & $\sim 150$ & $\sim 80$ & $\sim 40$ \\
\hline
\end{tabular}

The viscosity results from both references for undiluted wastes at tank temperature and a $400 \mathrm{sec}^{-1}$ shear rate show good agreement. When shear rate is expressed as the pipe flow velocity divided by the pipe inner radius, a $6 \mathrm{ft} / \mathrm{sec}$ flow velocity corresponds to a shear rate of about $50 \mathrm{sec}^{-1}$.in a $3^{\prime \prime}$ ID pipe. At this shear rate, Reference (1) indicates an in situ waste viscosity of about $100 \mathrm{cP}$

A summary of selected data for tank $241-\mathrm{SY}-101$ waste at $50^{\circ} \mathrm{C}$ from Reference (2) is reproduced below:

\begin{tabular}{|l|l|l|l|l|l|}
\hline $\begin{array}{l}\text { Dilution } \\
\text { Property }\end{array}$ & 0 vol\% & 10 vol\% & 20 vol\% & 35 vol\% & 50 vol\% \\
\hline $\begin{array}{l}\text { Apparent } \\
\text { Viscosity at } \\
400 \text { sec }^{-1}(\mathrm{cP})\end{array}$ & 39.4 & 35.8 & 12.3 & 6.8 & 2.9 \\
\hline $\begin{array}{l}\text { Vol\% settled } \\
\text { solids }\end{array}$ & 100 & 100 & 96 & 89 & 34 \\
\hline $\begin{array}{l}\text { Wt\% filtered } \\
\text { solids }\end{array}$ & 83 & 60 & 68 & 40 & 25 \\
\hline $\begin{array}{l}\text { Settled solids } \\
\text { density }\end{array}$ & 1.72 & 1.68 & 1.59 & 1.51 & 1.42 \\
\hline $\begin{array}{l}\text { Slurry } \\
\text { density }\end{array}$ & 1.72 & 1.68 & 1.60 & 1.48 & 1.34 \\
\hline
\end{tabular}

The value of 50 vol\% dilution corresponds to the minimum dilution specified for the RAPID transfer system. Based on the shear viscosity behavior reported in Reference (2), the viscosity at $50 \mathrm{sec}^{-1}$ shear rate would appear to be 2.4 times larger than the value at $400 \mathrm{sec}^{-1}$. The viscosity of water at $50^{\circ} \mathrm{C}$ is $0.55 \mathrm{cP}$.

For a $50 \mathrm{sec}^{-1}$ shear rate, the following table of tank 241-SY-101 waste viscosities could be derived from data in References (1) and (2):

\begin{tabular}{|l|l|l|l|l|l|}
\hline $\begin{array}{l}\text { Dilution } \\
\text { Property }\end{array}$ & 0 vol\% & $10 \mathrm{vol} \%$ & $20 \mathrm{vol} \%$ & $35 \mathrm{vol} \%$ & $50 \mathrm{vol} \%$ \\
\hline $\begin{array}{l}\text { Apparent } \\
\begin{array}{l}\text { Viscosity at } \\
50 \mathrm{sec}^{-1}(\mathrm{cP})\end{array}\end{array}$ & 100 & 85 & 30 & 16 & 7.0 \\
\hline
\end{tabular}

HNF-3885

Rev. 0 
W. J. Powell .

Page 5

February 11, 1999

This suggests a slurry viscosity expression in the form of:

$\mu_{m}=0.55 c P * \exp \left[k\left(\frac{\rho_{m}-1.0^{g m} / c c}{1.0^{g m} / c c}\right)\right] \quad$ where

$100 c P=0.55 c P * \exp \left[k\left(\frac{1.6^{\mathrm{gm} / c c}-1.0^{\mathrm{gm} / c c}}{1.0^{\mathrm{gm}} / \mathrm{cc}}\right)\right]$

since $\mu_{\mathrm{m}}=100 \mathrm{cP}$ when $\rho_{\mathrm{m}}=1.6 \mathrm{gm} / \mathrm{cc}$. This yields $\mathrm{k}=8.67$.

Therefore, at $50^{\circ} \mathrm{C},\left(\sim 120^{\circ} \mathrm{F}\right)$ and a shear rate of $50 \mathrm{sec}^{-1}$, the expression for the slurry viscosity produced by the RAPID transfer system becomes:

$\mu_{m}:=0.55 c P * \exp \left[8.67 *\left(\frac{\rho_{m}-1.0^{g m} / c c}{1.0^{g m} / c c}\right)\right]$

This expression yields the following results:

Slurry Viscosity Behavior at $120^{\circ} \mathrm{F}$ and $50 \mathrm{sec}^{-1}$ Shear Rate

\begin{tabular}{|c|c|c|}
\hline Slurry Density (gm/cc) & Mean Viscosity (cP) & Maximum Viscosity (cP) \\
\hline $\begin{array}{c}1.6 \\
\text { (corresponding to no dilution) }\end{array}$ & 100 & 200 \\
\hline $\begin{array}{c}1.4 \\
\text { (corresponding to minimum } \\
\text { specified dilution of 1 part water to } \\
\text { 2 parts waste) }\end{array}$ & 18 & 36 \\
\hline $\begin{array}{c}1.3 \\
\text { (corresponding to mean dilution of } \\
1 \text { part water to 1 part waste) }\end{array}$ & 7.4 & 15 \\
\hline $\begin{array}{c}1.2 \\
\text { (corresponding to maximum } \\
\text { dilution of 2 parts water to 1 part } \\
\text { waste) }\end{array}$ & 3.1 & 6.2 \\
\hline $\begin{array}{c}\text { 1.0 } \\
\text { (corresponding to infinite dilution) }\end{array}$ & & \\
\hline
\end{tabular}

HNF-3885

Rev. 0

A-5 
Page 6

February 11, 1999

(4) From the above table, at the specified RAPID transfer system operating temperature of $120^{\circ} \mathrm{F}$, the minimum specified dilution of 1 part by volume water to 2 parts by volume waste yields a slurry with an estimated viscosity of less than $30 \mathrm{cP}$. Only in the extreme of low dilution at the high viscosity bound does it exceed $30 \mathrm{cP}$. At the mean $1: 1$ dilution, the expected slurry viscosity is about $7.5 \mathrm{cP}$ with an expected maximum of $15 \mathrm{cP}$.

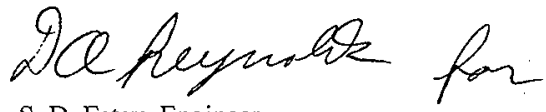

S. D. Estey, Engineer

Process Control

sde/mjg 
HNF-3885

Rev. 0

Feb. 24, 1999

\section{APPENDIX B}

FLAMMABLE GAS EQUIPMENT ADVISORY BOARD MEETING MINUTES

(FOR INFORMATION ONLY) 
MEETING MINUTES

SUBJECT: FLAMMABLE GAS EQUIPMENT ADVISORY BOARD (FGEAB) MEETING

TO:

DISTRIBUTION

BUILDING

2750E/A-229

FROM:

CC Scaief III

CHAIRMAN

RL Schlosser

DEPARTMENT-OPERATION-

COMPONENT

TWRS-Equipment Engineering

Members or Alternates/Attendees $\left({ }^{*}\right)$

JR Kriskovich CC Scaief III* RL Schlosser* DB Smet* RA Wahlquist

RA Huckfeldt* RE Larson

Other Attendees

TR Benegas

JM Grigsby

CE Hanson

\section{Meeting Minutes}

The meeting began at 2:00 p.m. and the subject was sealing of a new pump pit associated with pumping of SY-101 waste. The question of the drain seal integrity was discussed to determine the pit classification. If the pit were considered dome space it would be subject to the ignition controls associated with the same. The Board members present agreed that if the pit had a mechanical seal or a seal pot that would seal against the largest historically observed pressurization, it would be adequate to consider the pit non intrusive. It was felt that a $50 \%$ safety margin for a seal was sufficient. This would mean a seal with about 9 or 10 inches water head. The Board members also stated that some venting of the pit would be required to ensure no buildup of flammable gases.

Carl Hanson also discussed arranging a formal design review board that would include appropriate members of the FGEAB. Rich Schlosser indicated that he would provide a suggested review board membership based on the design and requirements. This portion of the meeting ended at about 3:00 p.m.

Todd Brown arrived to discuss the use of a caustic addition hose made of EPDM (Ethylene Propylene Rubber). The material has a high resistivity and the inside of the hose would be exposed to the dome space at the start of addition (after the riser valve was opened). The Board indicated that there might be some potential for charge generation due to dragging of the hose on the ground. This charge could conceivably be discharged on the inside of the hose by the conductive caustic. Wetting the outside of the hose could mitigate the charging. Dave Smet suggested that the hose was being enclosed in static dissipative sleeving (for containment of caustic leak). If this were true, then wetting would not be required. Todd agreed to find out about the sleeving.

The Board also discussed a request by Jeff Ranschau (not present) for a general ruling on the use of DC battery powered flashlights. Chuck Scaief agreed to add them to a report with some bounds on voltage and power based on the ignition curves for resistive circuits. The meeting adjourned at 3:30 p.m. 
HNF-3885

Rev. 0

Feb. 24, 1999

\section{APPENDIX C}

\section{PROCESS FLOW DIAGRAM}

(FOR INFORMATION ONLY)

$$
\text { C.P }
$$




\begin{tabular}{|c|c|c|c|c|c|c|c|c|c|c|c|c|c|c|c|c|c|c|}
\hline 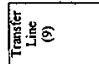 & $\approx$ & & $i$ & & & & & & & & & & & & 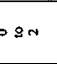 & & 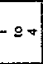 & 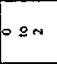 \\
\hline 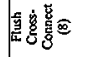 & $\tilde{z}$ & $\frac{\hat{z}}{2}$ & $\frac{\tilde{x}}{z}$ & 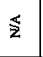 & $\frac{\mathbf{z}}{\mathbf{z}}$ & 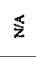 & $\frac{x}{2}$ & $\frac{\tilde{z}}{2}$ & $\underline{z}$ & $\underline{\hat{z}}$ & $\frac{\hat{z}}{z}$ & $\frac{\hat{z}}{z}$ & $\underline{\underline{z}}$ & $\underline{\underline{z}}$ & $\widehat{\widehat{\Lambda}}$ & $\frac{\hat{\Sigma}}{\hat{z}}$ & $\underline{\underline{z}}$ & $\underline{z}$ \\
\hline 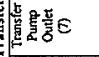 & $\approx$ & & & & & & & & & $\therefore$ & & & & & ○N & 0. & $\therefore=$ & $0 \Omega \sim$ \\
\hline 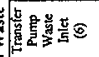 & $=0 \alpha$ & $\frac{\hat{z}}{\bar{z}}$ & & & 898 & 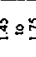 & $n=\pi$ & 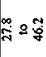 & 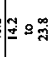 & $\infty 8$ & $p=$ & $\because \therefore$ & 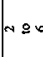 & $=27$ & $-9 m$ & $0 \therefore N$ & $\because 0$ & $-2 m$ \\
\hline 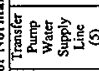 & 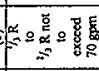 & $\frac{\pi}{2}$ & & $=8$ & 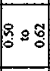 & $\vec{v}$ & ì & $\underline{8}$ & 。 & 。 & 。 & 。 & 。 & 。 & 。 & $\circ$ & 。 & - \\
\hline 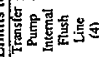 & $\Sigma$ & $\frac{1}{x}$ & $\hat{z}$ & $\frac{\Upsilon}{z}$ & $\frac{\hat{z}}{\mathbf{z}}$ & $\frac{1}{z}$ & $\underline{\underline{z}}$ & $\underline{z}$ & $\underline{\underline{z}}$ & $\underline{\underline{z}}$ & $\underline{\underline{z}}$ & 育 & $\bar{z}$ & $\underline{\underline{z}}$ & $\underline{z}$ & $\frac{s}{z}$ & $\widehat{\Sigma}$ & 童 \\
\hline 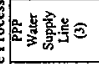 & 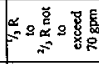 & $\frac{1}{2}$ & & & ํํㅇㅇ. & $\bar{v}$ & iे & 8 & 0 & 。 & $\circ$ & 。 & 。 & . & 。 & $\circ$ & $\circ$ & 0 \\
\hline 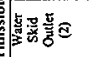 & 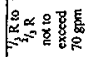 & $\frac{\hat{z}}{\hat{z}}$ & & & $8 \%$ & $\bar{v}$ & $\mid \bar{g}$ & $g$ & $\circ$ & . & 。 & 10 & . & . & 。 & $\circ$ & 0 & $\circ$ \\
\hline 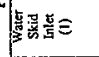 & ' & 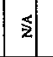 & & ' & i & $\bar{v}$ & io & $\underline{8}$ & $\circ$ & . & 。 & . & 。 & 0 & 。 & $\circ$ & 。 & 10 \\
\hline 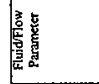 & $\frac{3}{3}$ & & & & & & & & & & & & & & $\frac{8}{20}$ & & & 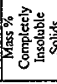 \\
\hline
\end{tabular}

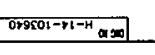

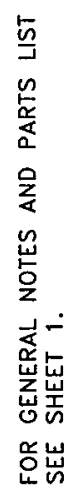

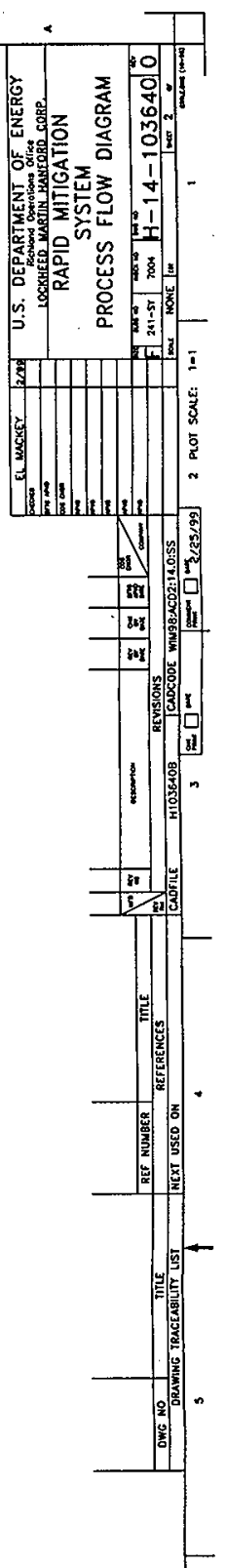

\begin{tabular}{|c|c|c|c|c|c|c|}
\hline 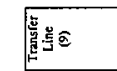 & 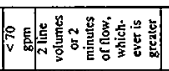 & $\stackrel{\square}{\square}$ & $\cong ?$ & $=0$ & 8 & 80 \\
\hline 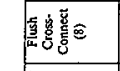 & 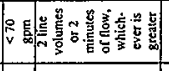 & $\stackrel{\circ}{\stackrel{\circ}{\circ}}$ & 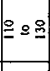 & 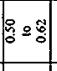 & \begin{tabular}{|l|l}
5 & 8 \\
\end{tabular} & 8. \\
\hline 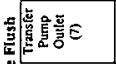 & $\frac{\underline{x}}{2}$ & $\frac{x}{\vec{z}}$ & $\frac{1}{2}$ & $\frac{1}{z}$ & 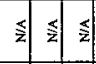 & $\frac{5}{2} \mid \frac{5}{2}$ \\
\hline 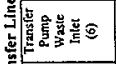 & $\underline{E}$ & $\frac{\widehat{x}}{\bar{z}}$ & $\frac{\tilde{z}}{2}$ & $\frac{x}{2}$ & $\frac{\pi}{2} \frac{\sqrt{2}}{2}$ & $\frac{\pi}{2} \frac{\pi}{2}$ \\
\hline 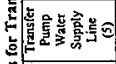 & 格 & $\hat{z}$ & $\frac{\hat{z}}{2}$ & $\frac{\underline{s}}{z}$ & $\frac{3}{2} \frac{1}{2}$ & $\frac{\hat{x}}{\hat{x}}$ \\
\hline 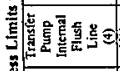 & 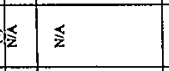 & $\frac{\pi}{2}$ & $\frac{\bar{x}}{2}$ & $\frac{\pi}{2}$ & 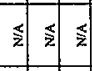 & $\frac{5}{2}$ \\
\hline 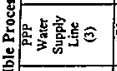 & 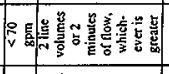 & & & $8=\%$ & $\overrightarrow{\mathrm{v}} \mathrm{\overline { \textrm {v } }}$ & 8. \\
\hline 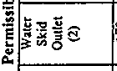 & 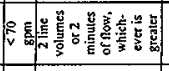 & & & 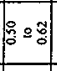 & $=8$ & 8. \\
\hline 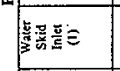 & 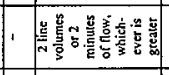 & & 1 & & $=8$ & 8. \\
\hline & 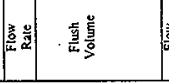 & & & & & 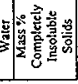 \\
\hline
\end{tabular}

\begin{tabular}{|c|c|c|c|c|c|c|}
\hline 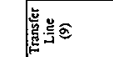 & $\frac{\pi}{z}$ & $\frac{5}{\bar{z}} \mid \frac{\hat{z}}{z}$ & $\mid \frac{\widehat{x}}{\bar{z}}$ & $\frac{\pi}{z}$ & $\frac{s}{z} \mid \frac{s}{z}=\frac{s}{z}$ & $\mid \frac{5}{2}$ \\
\hline 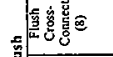 & $\frac{1}{2}$ & $\hat{\underline{2}} \frac{\hat{z}}{\mathbf{z}}$ & $\frac{\underline{x}}{\underline{z}}$ & 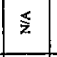 & & $\frac{\hat{z}}{\mathbf{z}}$ \\
\hline 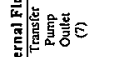 & $\frac{\tilde{x}}{\mathrm{z}}$ & $\frac{1}{\tilde{Z}}$ & 豙 & $\mid \frac{\mathfrak{s}}{\grave{z}}$ & $\bar{z}\left|\frac{s}{z}\right| \frac{s}{z} \mid$ & 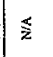 \\
\hline 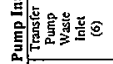 & 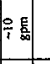 & & & 200 & 高 & 0 \\
\hline 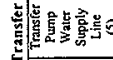 & $=\frac{1}{2}$ & $\hat{z}$ & $\frac{5}{z}$ & $\underline{\underline{z}}$ & $\frac{\hat{v}}{\hat{z}} \mid \frac{\hat{v}}{\hat{z}}$ & $\frac{\hat{z}}{\underline{z}}$ \\
\hline 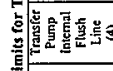 & 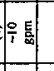 & & & 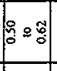 & : & 0 \\
\hline 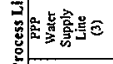 & 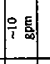 & & 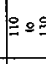 & $8=5$ & $=8$ & 。 \\
\hline 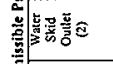 & : & & 0 & 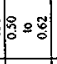 & $=\square$ & 0 \\
\hline 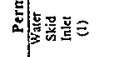 & & & ' & & 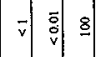 & 0 \\
\hline & & & & & & \\
\hline
\end{tabular}

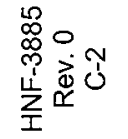

\begin{tabular}{|c|c|c|c|c|c|c|}
\hline 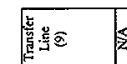 & $\varepsilon$ & $\frac{\Sigma}{\Sigma}$ & \begin{tabular}{l|l}
$\frac{1}{2}$ & $\frac{1}{2}$
\end{tabular} & $\frac{\hat{z}}{z}$ & 令 & $\underline{z}$ \\
\hline 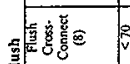 & 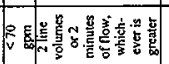 & $\stackrel{\circ}{a}=$ & $=202=8$ & $=$ & : & $\circ$ \\
\hline 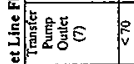 & 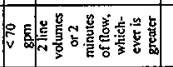 & $\vdots=$ & $=20 \% 9$ & \begin{tabular}{l|l|l|}
$\circ$ & $\bar{v}$
\end{tabular} & 产 & . \\
\hline 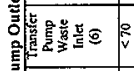 & 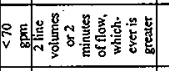 & & $=28=38$ & $\therefore:$ & \begin{tabular}{|l|l|}
5 & 8 \\
\end{tabular} & $\circ$ \\
\hline 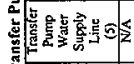 & $\frac{\hat{z}}{z}$ & $\underline{z}$ & \begin{tabular}{|l|l|}
$\underline{z}$ & $\widehat{\Sigma}$ \\
\end{tabular} & . & $\frac{x}{2}$ & $\frac{\pi}{2}$ \\
\hline 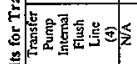 & $\underline{z}$ & $\widehat{\mathbf{z}}$ & \begin{tabular}{l|l}
$\hat{z}$ & $\frac{1}{z}$ \\
\end{tabular} & $\frac{1}{2}$ & 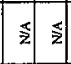 & $\frac{\pi}{2}$ \\
\hline 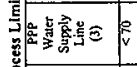 & 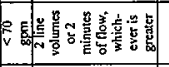 & & 38 & & 8 & $\circ$ \\
\hline 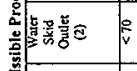 & 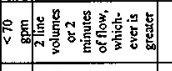 & & & $2: \vec{v}$ & $\begin{array}{|ll|}5 & 8 \\
\end{array}$ & $\circ$ \\
\hline 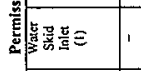 & 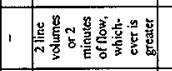 & &. & . $=$ & \begin{tabular}{|l|l|}
5 & 8 \\
& \\
\end{tabular} & $\circ$ \\
\hline 年 & $\frac{2}{3} \frac{2}{2}$ & & & & & 5 \\
\hline
\end{tabular}


HNF-3885

Rev. 0

Feb. 24, 1999

\section{APPENDIX D}

\section{NGTP FLANGE INTERFACE DRAWINGS}

(FOR INFORMATION ONLY)

D-O 


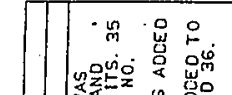

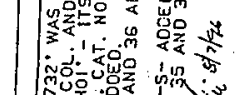

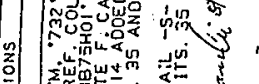

袋

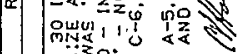

O.

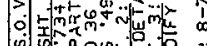

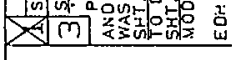

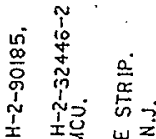

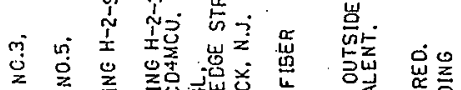

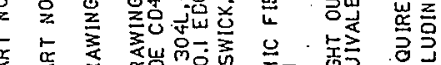

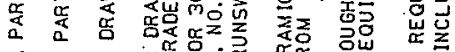

过

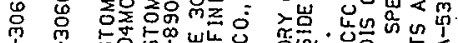

$\sim$ Novi

(x)

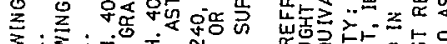

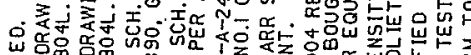

势

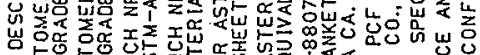

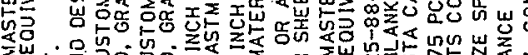

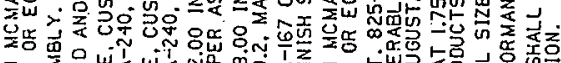

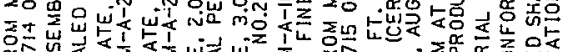

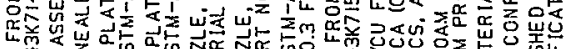

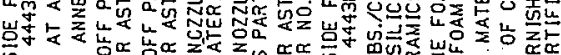

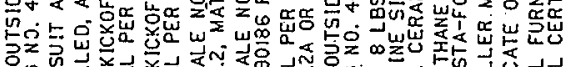

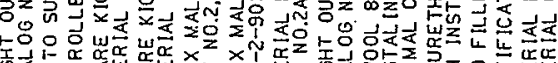

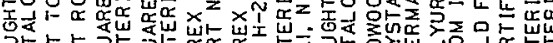

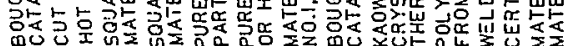

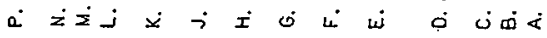

- .
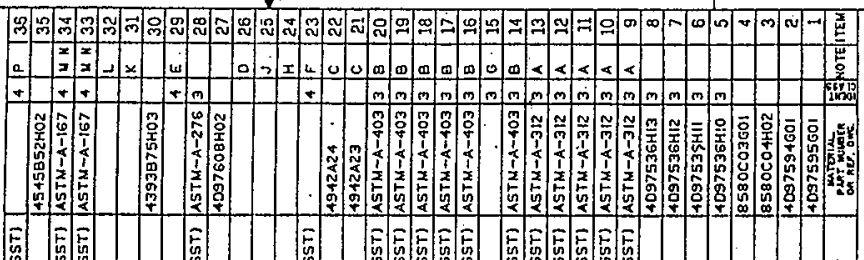

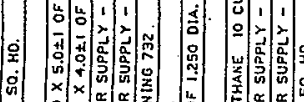

(a)

(a)

(n)

$\frac{1}{2}$

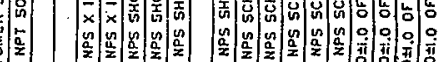

等

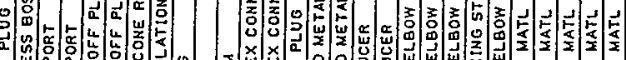

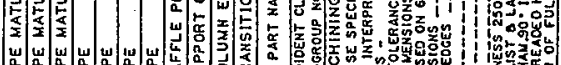

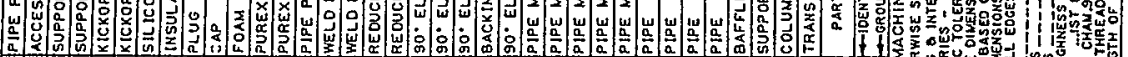

क

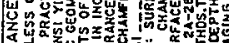

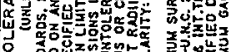

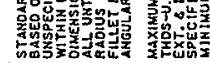

om

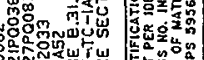
等

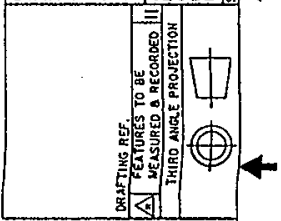

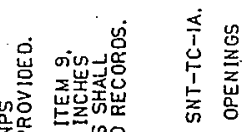

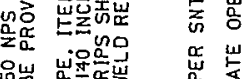

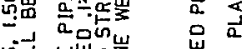

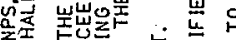

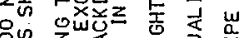

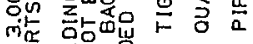

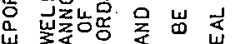

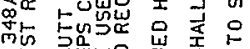

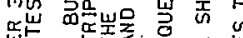

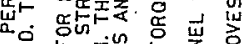

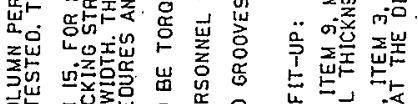

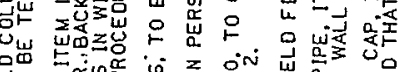

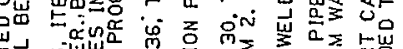

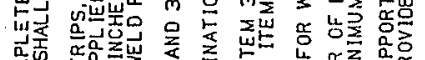

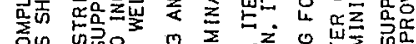

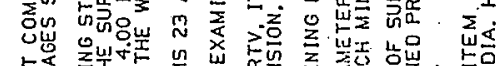

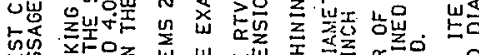

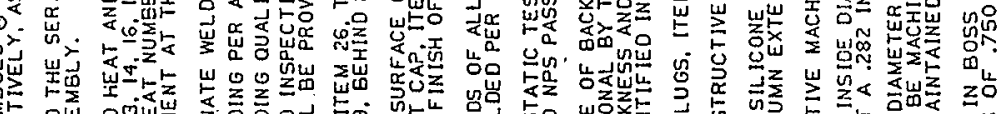

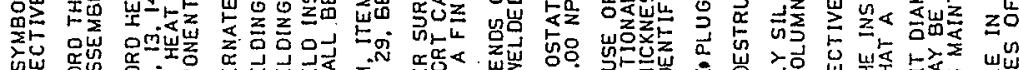

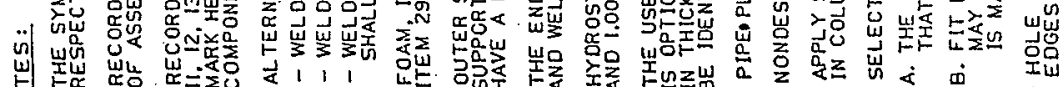

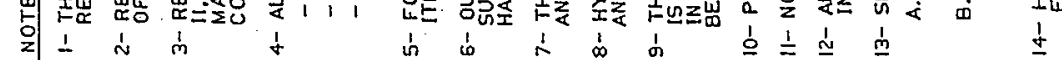

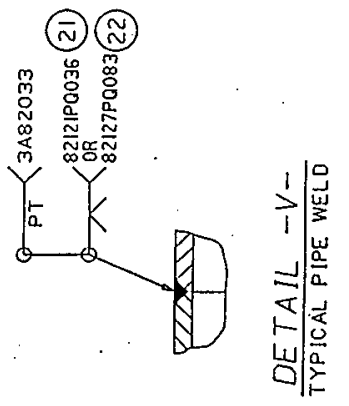

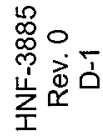
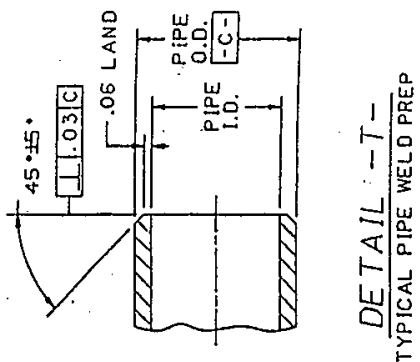


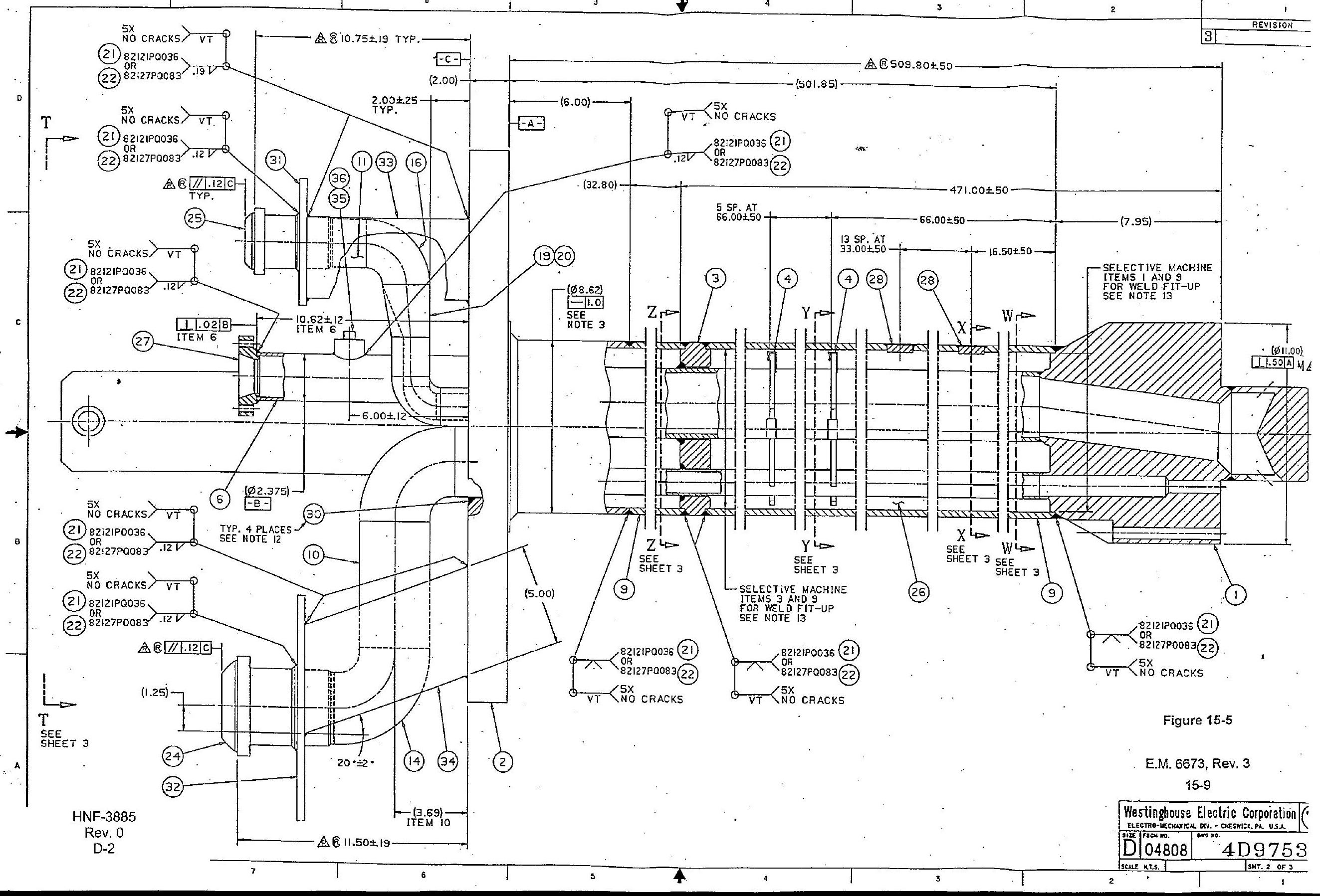




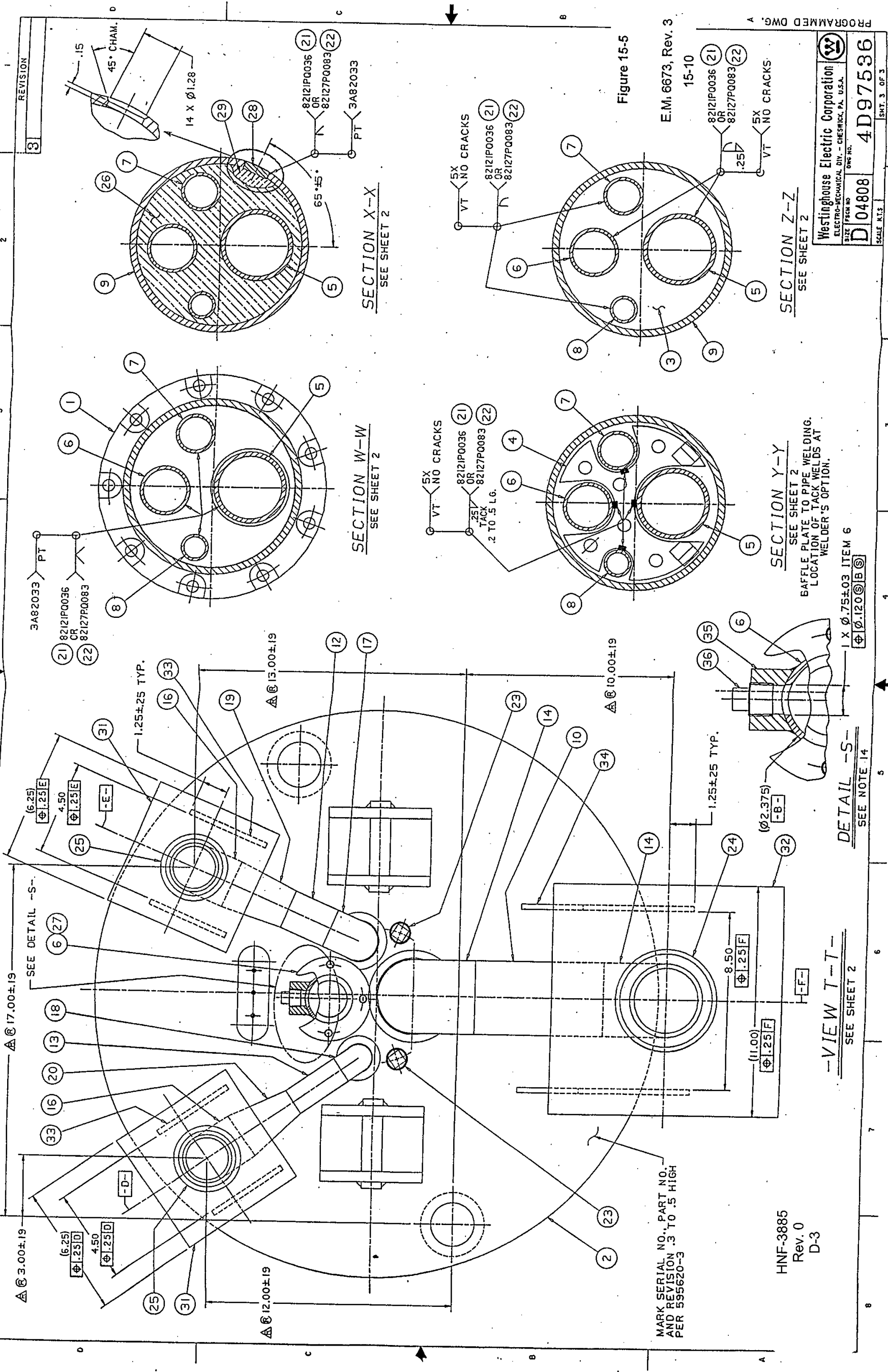


HNF-3885

Rev. 0

Feb. 24, 1999

\section{APPENDIXE}

\section{INTERNAL MEMO \\ (DRAFT)}

(FOR INFORMATION ONLY) 


$\begin{array}{ll}\text { From: } & \text { Process Control } \\ \text { Phone: } & 373-2711 \text { R2-11 } \\ \text { Date: } & \text { February 26, 1999 } \\ \text { Subject: } & \text { ESTIMATED PROPERTIES OF TANK 241-SY-101 WASTE AFFECTING } \\ & \text { DILUTION AND TRANSFER }\end{array}$

To:

$$
\text { W. J. Powell S5-13 }
$$

cc:
W. B. Barton
R2-12
R. E. Bauer
S7-73
J. W. Brothers
K9-20
C. Defigh-Price R2-12
M. F. Erhart R1-56
S. D. Estey R2-11
J. M. Grigsby S7-73
C. E. Hanson
S7-12
K. M. Hodgson
R2-11
G. D. Johnson
S7-73
N. W. Kirch
J. C. Person
R2-11
T6-07
R. E. Raymond
R2-38
D. A. Reynolds
S. W. Shaw
R2-11
JMC File/LB

References: (1) Letter, F. H. Steen, WMH, to K. M. Hall, LMHC, "Compatibility Analysis Results lor Tank 241-SY-101 Core Composites," WMH-9951091, dated February 24, 1999.

(2) Interoffice Memorandum, "Anticipated Dynamic Viscosity and Solids Concentration of Slurries Produced During the Dilution and Transfer of Tank 241-SY-101 Wastes to Tank 241-SY-102," 74B50-99-017, dated February 11, 1999.

(3) Letter of Instruction for Composition Studies on Samples Supposting Tank 241-SY-101 Level Growth Mitigation/Remediation,"74B50-99-011, dated February 8, 1999.

(4) Interoffice Memorandum, "Prediction of Dilution and Temperature Effects on Waste from Tank 241-SY-101," 74B50-98-061, dated December 15, 1998.

The purpose of this memo is to document estimates of tank 241-SY-101 (SY-101) waste properties relevant to the upcoming transfer. The information is needed to support process design documentation. Data on dynamic viscosity and overall solids concentration were provided previously (Reference 2). References are provided where possible. For some properties. the estimates are based on the opinion of tank waste chemistry experts. 
W. J. Powell

74B50-99-021

Page 2

February 26, 1999

\section{Insoluble Solids}

The overall solids loading in the SY-101 convective layer was previously estimated as 5 to 25 volume percent. The slurry concentration in the transfer line was estimated to vary from 2 to 17 volume percent with 7.5 as the mean (Reference 2).

The insoluble solids concentration of SY-101 the convective layer is estimated to be 3 weight percent or less. This is consistent with laboratory data and expert opinion. The concentration would be slightly lower on a volumetric basis because of the higher density of solids. The lab data (Reference 1) indicate insoluble metals ( $\mathrm{Ca}, \mathrm{Cr}, \mathrm{Fe}, \mathrm{Mn}, \mathrm{Ni}$, $\mathrm{Si}$, and $U$ ) are present at around 0.5 weight percent. This corresponds to approximately 1 to 1.5 weight percent as metal oxides in the waste. The remainder of the solids is at least partially soluble, depending on temperature and concentration.

Dissolution - Effect of Dilution Ratio

The effect of the water dilution ratio on solids dissolution has been studied using the OLI Environmental Simulation Program (ESP). The simulations indicate that dissolution of soluble salts is 87 percent complete at a dilution of 35 parts water to 100 parts waste and 98 percent complete at 50 parts water to 100 parts waste (Reference 4). Further dilution actually results in a slight increase in solids because of $\mathrm{pH}$-induced precipitation of aluminum hydroxide. The data are shown graphically in Figure 1.

These data support the preliminary conclusion that a dilution of 35 parts water to 100 parts waste is adequate, but a ratio of at least 50 parts water to 100 parts waste is desired. The target dilution range is from 50 to 150 parts water to 100 parts waste. Experimental results using actual waste samples are expected in April (Reference 3).

\section{Dissolution -Effect of Dilution Water Temperature}

The effect of dilution water temperature on solubility is also modeled in Reference 4. Increasing the temperature of the dilution water does not have as great an effect as increasing the dilution ratio. At a dilution ratio of 30 parts water to 100 parts waste, approximately $25 \%$ more soluble solids are present using $85^{\circ} \mathrm{F}$ dilution water than $130^{\circ} \mathrm{F}$ water. Additional data are provided in Figure 2. The target temperature range for dilution water has been specified as $110-130^{\circ} \mathrm{F}$ to allow operational flexibility. Any dilutions using water in this temperature range will result in lower overall solids concentrations.

A specific question was proposed regarding the net effect of diluting SY-101 waste with water at the nominal 1:1 ratio and allowing the mixture to equilibrate and cool to $65^{\circ} \mathrm{F}$ (which could happen in the discharge drop leg in tank 241-SY-102 (SY-102) if a siphon break occurred before line flushing). Although not modeled, it is anticipated that the final solids concentration would be lower than the initial, just-mixed concentration. That is, dissolution with the diluent is expected to have a stronger effect than the reduction in temperature. Figure 1 indicates that a 1:1 dilution is about 3 times more dilution water than is necessary to dissolve all $\mathrm{NaNO}_{3}$ at the temperature of $\mathrm{SY}-101\left(120^{\circ} \mathrm{F}\right)$. Even

HNF-3885

Rev. 0 
W. J. Powell

Page 3

February 26, 1999

upon cooling to $65^{\circ} \mathrm{F}$, much more $\mathrm{NaNO}_{3}$ will be dissolved in the diluted waste than in the original SY-101 waste.

\section{Dissolution/Precipitation Kinetics}

The overall kinetics of dissolution will be measured in the dilution and mixing study specified in Reference 3 . The consensus of tank waste chemistry experts is that dissolution of the nitrate, nitrite, carbonate, and phosphate solids should be fairly rapid (minutes). This may not have much effect on transfer properties, as the transit time to SY-102 will be less than one minute. Dissolution of oxalate is expected to take longer (hours).

Some precipitation of aluminum hydroxide is expected to occur because of the reduced $\mathrm{pH}$ of the diluted waste. This is known to be a slow process (days) and will not affect the pipeline behavior of the waste during the transfer. Although not expected to be a problem in the pipeline because of dilution, the precipitation of phosphates might occur within minutes and precipitation of oxalate and fluoro-phosphates within hours. The phosphate concentration in SY-101 waste is fairly low ( 0.5 weight percent from Reference 1). Precipitation of phosphates or fluoro-phosphate double salts may occur upon mixing with high phosphate saltwell liquors in SY-102. However, this is neither a pumping nor a pipeline transfer issue.

If you have any questions regarding the information provided, please call me at the above number.

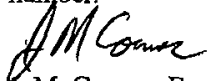

Y. M. Conner, Engineer

Process Control

$\mathrm{jmc/mjg}$ 
W. J. Powell

Page 4

74B50-99-021

February 26, 1999

Data from Reference 4

Figure 1. 100,000 Gallon Transfer from SY-101

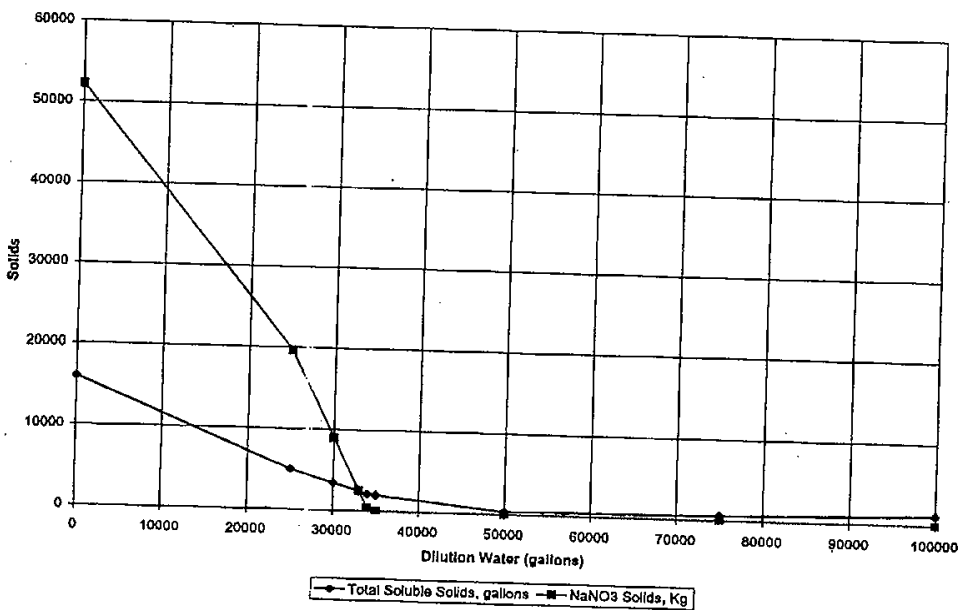

Figure 2. Effect of Dilution Water Temperature 100,000 Oallon Transfor from SY-101 100 Parts Waste to 30 Parts Water

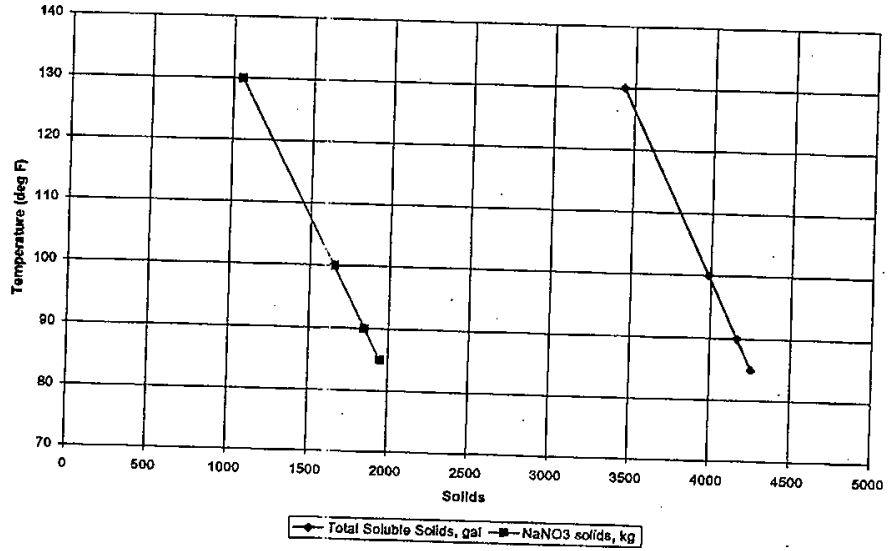

HNF-3885

Rev. 0

E-4 